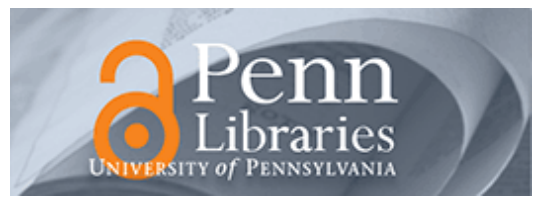

University of Pennsylvania

ScholarlyCommons

Accounting Papers

Wharton Faculty Research

$5-2007$

\title{
Which Institutional Investors Trade Based on Private Information About Earnings and Returns?
}

Brian J. Bushee

University of Pennsylvania

Theodore H. Goodman

Follow this and additional works at: https://repository.upenn.edu/accounting_papers

Part of the Accounting Commons

\section{Recommended Citation}

Bushee, B. J., \& Goodman, T. H. (2007). Which Institutional Investors Trade Based on Private Information About Earnings and Returns?. Journal of Accounting Research, 45 (2), 289-321. http://dx.doi.org/ 10.1111/j.1475-679X.2007.00234.x

This paper is posted at ScholarlyCommons. https://repository.upenn.edu/accounting_papers/55

For more information, please contact repository@pobox.upenn.edu. 


\title{
Which Institutional Investors Trade Based on Private Information About Earnings and Returns?
}

\begin{abstract}
Recent work suggests that institutional investors execute profitable trades based on private information about earnings and returns. We provide new evidence on the prevalence and sources of such informed trading by (1) testing for the creation and liquidation of positions based on private information, (2) introducing private information proxies that reflect the size and nature of an institution's position in each portfolio firm, and (3) using a methodology that examines multiple investor characteristics simultaneously at the institution-firm level. We find that changes in ownership by institutions with large positions in a firm are consistent with informed trading. However, other previously documented proxies for private information produce results more consistent with risk-based trading (e.g., investment style) or insignificant in the presence of other proxies (e.g., fiduciary type). We also find that informed trading is more prevalent in small firms and when the large positions are taken by investment advisers and large institutions.

Disciplines

Accounting
\end{abstract}




\title{
Which institutional investors trade based on private information about earnings and returns?
}

\author{
Brian J. Bushee \\ The Wharton School \\ University of Pennsylvania \\ 1300 Steinberg-Dietrich Hall \\ Philadelphia, PA 19104-6365 \\ bushee@wharton.upenn.edu \\ and \\ Theodore H. Goodman \\ Eller College of Management \\ University of Arizona \\ McClelland Hall \\ Tucson, AZ 85721-0108 \\ thg@wharton.upenn.edu
}

October 2005

We appreciate helpful comments and suggestions from Cathy Schrand, Shyam Sunder, Ro Verrecchia, and workshop participants at the Carnegie-Mellon University Accounting Conference. We are grateful for the funding of this research by the Wharton School and the University of Arizona. 


\title{
Which institutional investors trade based on private information about earnings and returns?
}

\begin{abstract}
Recent work presents evidence that certain groups of institutional investors are able to trade profitably based on private information about earnings and returns. We contribute to this literature in three ways. First, we test whether certain private information proxies are consistent with the creation and liquidation of positions based on private information. Second, we introduce private information proxies that reflect the size and nature of an institution's position in each portfolio firm. Third, we use a methodology that examines multiple investor characteristics simultaneously at the institution-firm-level. We find that changes in ownership by institutions that have large positions in a specific firm are consistent with trading based on private information. However, other previously-documented proxies for private information produce results that are more consistent with risk-based trading (e.g., investment style, portfolio turnover) or that are insignificant in the presence of the other proxies (e.g., fiduciary type). We also find that informed trading is more prevalent in return-based measures (vs. earnings-based measures) and in smaller firms. Tests for interactions among private information proxies reveal that informed trading is most evident when the large positions in firms are newly initiated and when they are taken by investment advisers and by large institutions. Finally, we find that institutions following growth strategies exhibit momentum trading in positions held less than one year and informed trading in positions held more than one year, suggesting that the information advantages to investment styles accrue over time.
\end{abstract}




\section{Introduction}

A growing literature suggests that institutional investors are able to execute profitable trades based on private information. These papers find that changes in holdings by institutional investors as a whole or specific subgroups (e.g., mutual funds or transient institutions) are positively associated with future firm earnings and returns (e.g., Ali et al. [2004], Pinnuck [2004], Ke and Petroni [2004], Ke and Ramalingegowda [2005]). These results are in contrast to other literatures that suggest more limited evidence of informed trading by institutions. For example, the mutual fund performance literature suggests that persistence of superior performance is not widespread (Jensen [1968], Brown and Goetzmann [1995]). Moreover, there is mixed evidence on informed trading by institutional investors using microstructure data. Dennis and Weston [2001] find a negative association between institutional ownership and both relative spreads and the probability of informed trading, but a positive association with the adverse selection component of the spread. Finally, prior work shows that institutional investors are attracted to firms with richer public information environments, including greater following by analysts (O’Brien and Bhushan [1990]) and higher disclosure quality (Bushee and Noe [2000]), suggesting less opportunity to obtain an information advantage if public and private information are substitutes. Based on this evidence, it is likely that informed trading by institutions, if it exists, is more limited in scope than suggested by the positive associations between overall institutional investor trading and future firm performance.

This paper provides new evidence on the prevalence and sources of informed trading by institutions in three ways. First, drawing on theoretical models of informed trading, we design tests to examine whether certain private information proxies are consistent with the creation and liquidation of positions based on private information. Second, we introduce proxies that capture 
the relation between an institutional investor and a given portfolio firm, such as the length of time the firm's equity has been held and the magnitude of its equity position. These proxies allow the amount of private information to vary both across institutional investor types (as in prior work) and within an institutions' portfolio. Finally, we use hierarchical linear modeling (HLM) to combine firm-level and institution-firm-level variables in one analysis, allowing us to examine multiple institutional investor characteristics simultaneously.

We find that changes in ownership by institutions that have created a large position in a specific firm (both in terms of percent ownership and percent of an institution's portfolio) are consistent with trading based on private information. Other previously-documented proxies for private information produce results that are more consistent with momentum or risk-based trading (e.g., investment style, portfolio turnover) or that are insignificant in the presence of the other proxies (e.g., fiduciary type). The clearest evidence of private information trading occurs with the return-based performance measures; there is limited evidence of informed trading related to earnings-based measures (e.g., analyst forecast errors). Finally, tests for interactions among private information proxies reveal that the length of time a position has been held and institution-level characteristics such as investment style and fiduciary type can have a secondorder effect on informed trading; i.e., interactions based on these factors explain additional significant differences in the prevalence of informed trading.

Prior work on informed trading by institutional investors has focused primarily on the change in ownership in advance of future performance. However, there is little evidence documenting whether the change in ownership following future performance is also consistent with completing the second half of a trading strategy (i.e., cashing out). Theoretical models where investors possess diverse information provide a structure for investigating how investors 
anticipate and react to news releases (e.g., Kim and Verrecchia [1991], [1997]). Drawing on this work, we develop a research design that allows for interpreting evidence of private information trading based on the relations between changes in ownership and past, current, and future firm performance. This design recognizes that if informed investors are trading in anticipation of future news, such trading should exhibit a positive association with future news and a negative association with previously-anticipated current and past news. Furthermore, we attempt to provide a more complete picture of the possible determinants of informed trading by using multiple proxies for outcomes which could be predicted using private information, such as quarterly and annual returns, analyst forecast errors, and earnings announcement returns.

While prior work has examined whether large groups of institutions, on average, possess private information about all portfolio stocks, we expect that the incidences where an institution has private information will be relatively infrequent because of the cost of obtaining private information. We examine a number of private information proxies at both the institution-level and the institution-firm-level to provide further insight into whether informed trading by institutions is a general phenomenon or is driven by only a small subset of institutional investor equity positions in firms. Following prior work, we test whether institution-specific characteristics—-such as fiduciary type (e.g., banks, pensions, investment advisors), trading strategy (value, growth, transient), and available resources (fund size) — are associated with an institutional investor group possessing more precise private information than the average investor. In addition, to identify conditions where a particular institution has private information about a particular portfolio firm, we examine the size and duration of an institution's stake in each portfolio firm and an institution's industry expertise related to each firm. 
Because there is considerable overlap across these different private information proxies, it is difficult to make inferences on a single characteristic without controlling for the other characteristics. To control for this overlap, we employ a HLM framework to examine each characteristic's relative importance for informed trading. Using this framework, we exploit within-firm variation in institutional investor characteristics to estimate the change in ownership in a given firm due to a particular characteristic (controlling for all other characteristics). Then, at the firm-level, we regress the sensitivity of changes in ownership to each characteristic on prior, current, and future firm performance to determine which private information proxies are associated with informed trading.

First, we estimate a "traditional" firm-level regression of changes in institutional ownership aggregated by type on firm performance measures. This approach provides comparability with prior work, but treats each private information proxy separately. We confirm prior findings of institutional trading in advance of future firm performance, including positive relations between changes in investment adviser ownership and future earnings-announcement returns (Ali et al. [2004], Pinnuck [2004]) and between changes in transient investor ownership and future earnings surprises (Ke and Petroni [2004]). However, while these and other institutional investor characteristics, such as growth styles and fund size, are positively related to future performance, they are also positively related to past and current performance, contrary to what would be expected if these institutions had previously anticipated the current news. This finding suggests momentum or risk-based trading rather than trading to reverse positions taken in the past based on private information. The results most consistent with informed trading are for institutions that hold large blocks and take big portfolio bets. These institutions exhibit both trading in advance of future performance and cashing out based on prior and current news. 
In the HLM estimation, we combine the multiple proxies for private information in one analysis. We find that almost all of the significant relations between the fiduciary type of the institution and trading based on current and future performance are rendered insignificant, suggesting that fiduciary type is subsumed by other private information proxies. In contrast, the HLM framework provides some evidence that industry expertise is associated with informed trading, whereas these relations were insignificant in the aggregated ownership regressions, consistent with a suppressor effect that is eliminated when other characteristics are controlled for. The most consistent evidence of private information trading occurs with the return-based performance measures. Other than a positive association between changes in transient institution holdings and future analyst forecast errors, there is little evidence of informed trading relative to earnings surprises. Finally, the strongest evidence of private information trading is again found among institutions that hold large positions in firms.

In supplemental analyses, we find that the evidence of informed trading by institutions with large positions in firms is concentrated in small firms, as would be expected given the relatively rich public information environments of large firms. In interaction tests, we find that private information trading is most evident when large positions in firms are taken by investment advisers, which have limited fiduciary responsibilities and lower risk aversion, and by large institutions, which have greater resources and potentially more access to management. We also find that results consistent with informed trading are only present for large positions held less than one year, suggesting that institutions are entering firms based on private information and cashing out when that information is realized in price. Finally, we find that institutions following growth strategies exhibit momentum trading in positions held less than one year and 
informed trading in positions held more than one year, suggesting that the information advantages to investment styles accrue over time.

This paper contributes to the literature by suggesting that informed trading is not as widespread as prior literature suggests. Prior work indicates that large groups of institutions with certain characteristics execute informed trades, on average, with respect to future earnings and earnings-announcement returns. By interpreting the coefficients on both current and future performance measures and controlling for multiple private information proxies in the same analysis, we find that informed trading is concentrated mainly in situations where an institutional investor has taken a large position in a firm in advance of future returns. We find little evidence in support of informed trading based on future earnings or earnings-announcement returns. ${ }^{1}$

The remainder of this paper is organized as follows. Section 2 describes the hypotheses development and related literature. Section 3 outlines the research design and variable measurement. Section 4 describes the sample selection. Section 5 presents the empirical results and is followed by the conclusion in section 6 .

\section{Hypothesis development}

\subsection{Prior research}

Prior empirical research often examines trading volume around information events for evidence that investors possess private information of heterogeneous quality (e.g., Beaver [1968]). Prior work has demonstrated that volume at an earnings announcement is positively associated with the dispersion among analysts before an earnings announcement (Ataise and Bamber [1994]) and the change in the dispersion in beliefs (Bamber, Barron, and Stober [1997]). Trading volume in the earnings announcement window is also sensitive to the prior percentage of

\footnotetext{
${ }^{1}$ A notable exception is that we find evidence that transient investors trade in advance of analysts forecast errors, consistent with Ke and Petroni [2004].
} 
total institutional ownership (Utama and Cready [1997]) and the prior percentage ownership by institutions with a given style (e.g. momentum, growth, high turnover) (Hotchkiss and Strickland [2003]). These findings indicate that institutional investors have differential amounts of private information about earnings, both relative to non-institutional investors and across different types of institutions. Such dispersion in private information has also been documented using stock returns. Badrinath and Wahal [2002] find a positive association between changes in ownership and lagged returns (momentum trading) that varies by fiduciary type (e.g., bank) and investment style (e.g., value/growth).

Prior work also examines whether institutional investors trade in a manner that predicts upcoming earnings news or returns. The presence of institutional investors is positively related to the extent that prices lead earnings, consistent with institutions making trades that impound information about future earnings in stock prices (Jiambalvo, et al. [2002]; Piotroski and Roulstone [2003]). Ke and Petroni [2004] find that transient investors (i.e., institutions that own small stakes and trade frequently) sell firms in the two quarters prior to a break in a sequence of positive earnings increases. Ke and Ramalingegowda [2005] find that transient institutions possess private information on long-term earnings that will be reflected in near-term stock prices (e.g., six months ahead) but do not have private information on long-term earnings that will be reflected in long-term stock prices. They also find that transient institutions can earn abnormal returns in excess of $10 \%$ on their private information. Ali, et al. [2004] documents that large changes in total institutional ownership precede abnormal returns around the next earnings announcement. Pinnuck [2004] finds that Australian mutual funds rebalance their holdings in anticipation of future returns based on earnings news. The latter three studies suggest that 
institutions not only have private information about upcoming earnings, but that they are able to profit from it as well.

We address a number of the limitations of these prior studies. ${ }^{2}$ First, the prior literature is mixed on whether the best test of informed trading should involve past, current, or future information. While many studies control for information in multiple periods to remove the effects of post-earnings announcement drift (Bernard and Thomas [1990]) or price momentum (Jagedessh and Titman [1993]), the coefficients on only the future period are generally considered as evidence on informed trading. We draw on existing theory to provide an empirical framework in which trading related to both current and future firm performance provides evidence on informed trading. Second, the prior literature generally uses fixed institutional investor characteristics as proxies for private information and examines levels or changes in holdings aggregated by each characteristic. We expect that institutions are likely to have private information in only certain portfolio firms and, thus, we introduce proxies that capture the characteristics of an institution's investment in each portfolio firm. We also use a methodology that examines multiple investor characteristics at the institution-firm-level, allowing tests of whether any previously-documented private information proxies are subsumed by other proxies.

\subsection{The precision of private information and informed trading}

We draw on the model of Kim and Verrecchia [1997] (KV) to develop predictions for the relations between informed trading by institutions and both current and future news. KV

\footnotetext{
${ }^{2}$ Because the data on specific institution holdings in the US is only available quarterly, there have been two approaches to testing for private information trading: (1) association tests between short-window volume/returns and the level of institutional ownership at the beginning of the quarter and (2) association tests between changes in quarterly holdings and short- or long-window returns and earnings. The drawback to the first approach is that the test is unsigned (i.e., it cannot be determined whether a specific institution bought or sold in a specific window) and the drawback to the second is that quarterly changes in holdings mask the timing of intra-quarter changes. We adopt the second approach in this paper because the sign of the change in holdings is important, and we provide evidence on various earnings and returns windows to partially mitigate the second drawback.
} 
articulates the relation between investor trades and the precision of two different types of private information: predicting the content of an announcement ("pre-announcement information") and interpreting the content of an announcement ("event-period information"). In a noisy rational expectations equilibrium with a single information announcement, they derive the change in an investor's demand after an announcement $\left(\mathrm{D}_{2 \mathrm{i}}-\mathrm{D}_{1 \mathrm{i}}\right)$ as a function of the relative precision of that investor's private information before $\left(\mathrm{s}_{1 \mathrm{i}}-\mathrm{s}_{1}\right)$ and after $\left(\mathrm{s}_{2 \mathrm{i}}-\mathrm{s}_{2}\right)$ the announcement, the returns preceding and following the announcement, and the investor's risk tolerance $\left(\mathrm{r}_{\mathrm{i}}\right)$ :

$$
\mathrm{D}_{2 \mathrm{i}}-\mathrm{D}_{1 \mathrm{i}}=\mathrm{r}_{\mathrm{i}}\left[\mathrm{s}_{2 \mathrm{i}} \varepsilon_{2 \mathrm{i}}+\left(\mathrm{s}_{1 \mathrm{i}}-\mathrm{s}_{1}\right)\left(\mathrm{P}_{1}-\mathrm{P}_{2}\right)+\left(\mathrm{s}_{2 \mathrm{i}}-\mathrm{s}_{2}\right)\left(\mathrm{u}-\mathrm{P}_{2}\right)\right]
$$

where $\mathrm{D}_{\mathrm{ti}}=$ demand for investor $\mathrm{i}$ at time $\mathrm{t}$;

$r_{i}=$ coefficient of risk tolerance for investor $i$;

$\mathrm{s}_{\mathrm{ti}}=$ the precision of investor i's private information at time $\mathrm{t}$;

$\mathrm{s}_{\mathrm{t}}=$ the average (or market's) precision of private information at time $\mathrm{t}$;

$\mathrm{P}_{\mathrm{t}}=$ price at time $\mathrm{t}$;

$\mathrm{u}=$ the liquidating dividend;

$\varepsilon_{2 \mathrm{i}}=$ error in investor i's private assessment of firm value

In this model, traders with more precise private information about the value of the firm before an announcement $\left(\mathrm{s}_{1 \mathrm{i}}-\mathrm{s}_{1}\right)$ take positions in the stock before news is released. These traders anticipate the announcement and, thus, learn less from the disclosure and price change; their changes in ownership are negatively related to the returns leading up to the announcement. This negative association can also be interpreted as institutions "cashing out" the profits from previous trades based on private information. Traders that are unable to anticipate the announcement will exhibit changes in ownership that are positively correlated with the concurrent price movement, which is indicative of learning from the announcement. Thus, we expect to see a negative relation between investor trading and current returns for those investors that had private information prior to the news release. 
Unlike the ability to anticipate news, the ability to interpret news does not influence the demand choice before the announcement occurs. However, the ability to interpret information released during a particular window will alter the trades of an institution during that window. Investors that have an advantage in interpreting a signal $\left(\mathrm{s}_{2 \mathrm{i}}-\mathrm{s}_{2}\right)$ will make trades that are positively associated with increases in future firm value following the announcement. Traders at a disadvantage in interpreting the signal will exhibit a negative relation between their trading and future returns. Thus, we expect a positive relation between investor trading and future returns for those investors that had more precise information based on their ability to interpret new information disclosed during the period.

In the empirical tests, we examine quarterly cross-sectional data that is not tied to a specific announcement, which is a significant deviation from the KV model. Consequently, one quarter's private event-period information will manifest as private pre-announcement information in the subsequent quarter. Thus, it is difficult to disentangle informed trading based on nonpublic private information obtained prior to a quarter from trading based on a more precise interpretation of public disclosure. However, for the purposes of our tests, the source of the information advantage is not important. Either type of information advantage should result in the same empirical findings: a negative (positive) association between current (future) news.

2.3 The precision of private information and observable investor characteristics

To incorporate the role of private information proxies, we make the following modifications to equation (1). First, we distribute the risk tolerance parameter across the terms, rewrite the current returns in the usual $\left(\mathrm{P}_{2}-\mathrm{P}_{1}\right)$ form, and add firm-level subscripts $(\mathrm{j})$ to highlight the fact that this equation will be estimated in a cross-section of firms:

$$
\Delta \mathrm{D}_{2 \mathrm{ij}}=\mathrm{r}_{\mathrm{i}} \mathrm{s}_{2 \mathrm{ij}} \varepsilon_{2 \mathrm{ij}}-\mathrm{r}_{\mathrm{i}}\left(\mathrm{s}_{1 \mathrm{ij}}-\mathrm{s}_{1 \mathrm{j}}\right) \Delta \mathrm{P}_{2 \mathrm{j}}+\mathrm{r}_{\mathrm{i}}\left(\mathrm{s}_{2 \mathrm{ij}}-\mathrm{s}_{2 \mathrm{j}}\right) \Delta \mathrm{P}_{3 \mathrm{j}}
$$


where $\Delta \mathrm{D}_{2 \mathrm{ij}}=\mathrm{D}_{2 \mathrm{ij}}-\mathrm{D}_{1 \mathrm{ij}} ; \Delta \mathrm{P}_{2 \mathrm{j}}=\mathrm{P}_{2 \mathrm{j}}-\mathrm{P}_{1 \mathrm{j}}$; and $\Delta \mathrm{P}_{3 \mathrm{j}}=\mathrm{u}_{\mathrm{j}}-\mathrm{P}_{2 \mathrm{j}}$

Equation (2) shows that risk aversion could offset any advantage of superior private information.

Thus, the absence of evidence in favor of informed trading could suggest a lack of private information or lower risk tolerance.

We include a number of possible proxies for private information. For simplicity, we only include two proxies in the following equation, one at the institution-firm-level $\left(\mathrm{X}_{1 \mathrm{ij}}\right)$ and one at the institution-level $\left(\mathrm{X}_{2 \mathrm{i}}\right)$. Both of these proxies are hypothesized to map into $\mathrm{r}_{\mathrm{i}}\left(\mathrm{s}_{\mathrm{tij}}-\mathrm{s}_{\mathrm{tj}}\right)$ in a linear way where the intercept term $\left(a_{\mathrm{j}}\right)$ is allowed to vary across firms. ${ }^{3}$

$$
\begin{aligned}
& \mathrm{r}_{\mathrm{i}}\left(\mathrm{s}_{1 \mathrm{ij}}-\mathrm{s}_{1 \mathrm{j}}\right)=\mathrm{a}_{1 \mathrm{j}}+\mathrm{b}_{1} \mathrm{X}_{1 \mathrm{ij}}+\mathrm{b}_{2} \mathrm{X}_{2 \mathrm{i}} \\
& \mathrm{r}_{\mathrm{i}}\left(\mathrm{s}_{2 \mathrm{ij}}-\mathrm{s}_{2 \mathrm{j}}\right)=\mathrm{a}_{2 \mathrm{j}}+\mathrm{b}_{3} \mathrm{X}_{1 \mathrm{ij}}+\mathrm{b}_{4} \mathrm{X}_{2 \mathrm{i}}
\end{aligned}
$$

where $\mathrm{X}_{1 \mathrm{ij}}=$ Private information proxy for institution $\mathrm{i}$ in firm $\mathrm{j}$;

$\mathrm{X}_{2 \mathrm{i}}=$ Private information proxy for institution $\mathrm{i}$;

$\mathrm{a}, \mathrm{b}=$ Linear weights

Now, we substitute equations (3) and (4) into equation (2):

$$
\begin{gathered}
\Delta \mathrm{D}_{2 \mathrm{ij}}=\left[\mathrm{a}_{2 \mathrm{j}}+\mathrm{b}_{3} \mathrm{X}_{1 \mathrm{ij}}+\mathrm{b}_{4} \mathrm{X}_{2 \mathrm{i}}+\mathrm{r}_{\mathrm{i}} \mathrm{s}_{2 \mathrm{j}}\right] \varepsilon_{2 \mathrm{ij}}-\left[\mathrm{a}_{1 \mathrm{j}}+\mathrm{b}_{1} \mathrm{X}_{1 \mathrm{ij}}+\mathrm{b}_{2} \mathrm{X}_{2 \mathrm{i}}\right] \Delta \mathrm{P}_{2 \mathrm{j}}+ \\
{\left[\mathrm{a}_{2 \mathrm{j}}+\mathrm{b}_{3} \mathrm{X}_{1 \mathrm{ij}}+\mathrm{b}_{4} \mathrm{X}_{2 \mathrm{i}}\right] \Delta \mathrm{P}_{3 \mathrm{j}}}
\end{gathered}
$$

Rearranging equation (5) and substituting regression parameters for the theoretical constructs leads to our hypothesized relation between changes in individual institutional investor holdings, private information proxies, and current and future returns:

$$
\Delta D_{2 i j}=\alpha_{j}+\left[\beta_{1} X_{1 i j}+\beta_{2} X_{2 i}\right] \Delta P_{2 j}+\left[\beta_{3} X_{1 i j}+\beta_{4} X_{2 i}\right] \Delta P_{3 j}+v_{i j}
$$

where $\alpha_{j}=-a_{1 j} \Delta P_{2 j}+a_{2 j} \Delta P_{3 j}$ (firm fixed effect);

$$
\begin{aligned}
& \beta_{1}=-b_{1} ; \beta_{2}=-b_{2} ; \beta_{3}=b_{3} ; \beta_{4}=b_{4 ;} \\
& v_{i j}=\left[a_{2 j}+b_{3} X_{1 i j}+b_{4} X_{2 i}+r_{i} s_{2 j}\right] \varepsilon_{2 i j} \text { (error term); }
\end{aligned}
$$

Hypothesis 1: Changes in institutional holdings will be negatively related to private information proxies interacted with current returns (i.e., $\beta_{1}<0, \beta_{2}<0$ )

\footnotetext{
${ }^{3}$ The theoretical precision construct is calculated relative to an average for each firm. The firm-specific intercept ensures that the characteristics we examine are also mean zero for each firm.
} 
Hypothesis 2: Changes in institutional holdings will be positively related to private information proxies interacted with future returns (i.e., $\beta_{3}>0, \beta_{4}>0$ )

Support for both hypothesis 1 and hypothesis 2 would provide strong and consistent evidence that informed trading is associated with a given private information proxy. However, if only one of the two hypotheses is supported, care must be exercised in interpreting the results because there are other potential explanations. For example, if a certain proxy represents institutions buying riskier firms with higher expected returns, then both $\beta_{2}$ and $\beta_{4}$ will be positive; whereas private information trading should result in only $\beta_{4}$ being positive, with $\beta_{2}$ either negative or zero. As another example, if hypothesis 1 is supported $\left(\beta_{2}<0\right)$ but hypothesis 2 is rejected because $\beta_{4}$ is not significantly different from zero, it could either mean that the institution is trading based on long-term private information (i.e., we observe the anticipation/cash-out but not the trading in advance of short-term future performance) or that the institution is following a contrarian strategy of selling winners and buying losers solely based on the realized returns. We will run additional analysis to attempt to disentangle such explanations.

\section{Research Design}

\subsection{Variable Measurement}

\subsubsection{Private information proxies}

We include a number of possible proxies for private information to represent situations in which an institution is more likely to have an information processing advantage, greater incentives to incur the costs of information gathering, and/or increased access to management. In each case, we create an indicator variable for the private information proxy to facilitate interpretation of the interaction terms. The Appendix presents all variable definitions and a timeline of when each variable is measured. 
Our institutional-investor-level private information proxies include the institution's investment style, its trading behavior, the resources available to produce private information, and its fiduciary obligations. We examine two investment style classifications: VALUE and GROWTH. ${ }^{4}$ We assume that institutions choose to specialize in a specific style rather than hold a broad index because these institutions have more expertise than the average investor in valuing certain firms. If this valuation expertise is due to the possession of private information and/or the ability to interpret a given firm's results, we expect that GROWTH and/or VALUE will be associated with private information trading.

We also examine whether trading behavior is associated with incentives to earn shortterm trading profits. We identify TRANSIENT institutional investors using the classification in Bushee [2001], which characterizes transient investors as having high portfolio turnover and small stake sizes. TRANSIENT institutions have strong incentives to gather private information because they are engaging in strategies to profit from short-term price appreciation, as opposed to dedicated and transient institutions, which follow longer-term buy-and-hold strategies (Bushee [2001]). Ke and Petroni [2004] find that TRANSIENT institutions are more likely to sell a firm before it has a break in a long sequence of earnings increases, consistent with their incentives to gather short-term private information. Thus, we expect TRANSIENT to be associated with private information trading.

Next, we use the size of the institutional investor to proxy for resources available to gather private information. We define the variable LARGE to equal one if the market value of an institutions' equity portfolio is in the top quintile for all institutions in a given quarter and

\footnotetext{
${ }^{4}$ These classifications are based on the factor analysis in Abarbanell et al. [2003], which produces a "value" factor based on each institution's portfolio weighted-average earnings-to-price ratio, book-to-price ratio, and dividend yield. We perform a k-means cluster analysis to split institutions into three groups based on the value factor; the top (bottom) group of institutions is classified as VALUE (GROWTH) institutions.
} 
zero otherwise. LARGE should proxy for private information if larger institutions have greater access to firm management or have better processing capabilities due to economies of scale or a larger pool of buy-side analysts. In addition, LARGE may measure the perceptions of individual contributors to the institutions. If individuals allocate their wealth to institutions based on perceived information advantages, then more informed institutions will have more assets under management. Thus, we expect that LARGE will be associated with private information trading.

Our final institution-level characteristic captures an institution's fiduciary type. Because the enforcement of fiduciary responsibility centers on the prudence of investment decisions, managers of banks and pensions, which face stricter standards under common law and ERISA, should behave in a more risk averse manner than managers of mutual funds/investment advisors, which are largely absolved from fiduciary responsibility by the Investment Company Act of 1940 (Del Guercio [1996], Abarbanell, et al. [2003]). We classify institutions into four categories: bank trusts (BANK), investment advisors (IIA), pensions and endowments (P\&E), and insurance companies, as in Abarbanell et al. [2003]. We create indicator variables for the first three categories, making insurance companies the omitted group. While we do not place any prediction on these variables with respect to the precision of private information, we expect a weaker sensitivity of changes in holdings to different price movements for BANK and P\&E due to their lower levels of risk tolerance. ${ }^{5}$

Our private information proxies that capture the institution's position in a given firm include the percent of total shares outstanding held by the institution, the percent of institution's portfolio concentrated in a given firm, the length of time the firm has been held, and a measure of expertise in the firm's industry. We define the variable for large holdings in a firm, BLOCK,

\footnotetext{
${ }^{5}$ Ali, et al. [2004] use this classification as a proxy for differences in investment style / trading orientation. However, because we have more direct measures of these attributes, we expect that differences in fiduciary type are more likely to reflect risk aversion than private information collection.
} 
as an indicator variable equal to one if the percent of total shares outstanding held by the institution is in the top quintile for the firm and zero otherwise. ${ }^{6}$ We expect BLOCK to be associated with private information trading as large stakeholders generally have more access to management and greater incentives to incur the costs of private information acquisition.

Moreover, the large stake size itself could reflect the fact that the institution believes that it has an information advantage in the stock.

We also define a indicator for large portfolio bets in a given firm, BET, which equals one if the percent of the institution's equity portfolio invested in a firm is in the top quintile for the firm and zero otherwise. BET captures the extent to which an institution is over-weighted in a given firm, which again creates stronger incentives to gather private information and likely reflects the institution believing that it holds superior information in the firm. While BET and BLOCK are likely to be positively correlated, BET is probably a better measure of incentives to gather private information about the firm and BLOCK is a better measure of the institution's access to management.

Next, we define long-term holdings, LTHELD, as an indicator variable equal to one if the institution has held the firm continuously for at least one year and zero otherwise. ${ }^{7}$ We expect LTHELD to be associated with private information trading as it reflects the accumulation of firm-specific knowledge over an entire fiscal year, which should aid in interpreting any public disclosures, as well as reflecting a potentially closer relationship with management due to the institution's commitment to holding the firm.

\footnotetext{
${ }^{6}$ While blockholder ownership is often defined as $5 \%$ or $2 \%$ ownership in a given firm, we wanted to define this variable such that there were some institutions in all firms that had a value of one for this measure. It is likely that, even in firms with highly disperse holdings, institutions that have larger stake sizes still have greater incentives to gather private information in the firm than other investors.

${ }_{7}^{7}$ Although we chose the one year benchmark to capture institutions that have held a firm through an entire fiscal year, five quarters held is also the median of the distribution of the numbers of quarter held.
} 
Finally, we measure the amount of potential expertise the institution has in a given firm's industry. We compute the percent of the institution's portfolio market value that is held in stocks in the same two-digit SIC as a given firm (excluding the firm) and define industry expertise, INDEXP, as an indicator variable equal to one if the industry holdings are in the top quintile for the firm and zero otherwise. We expect that INDEXP is associated with private information trading as it reflects the institution's ability to use industry-specific information gained in its other portfolio holdings to improve its interpretation of firm-specific information.

\subsubsection{Performance measures}

In $\mathrm{KV}$, the change in investor holdings occurs around a discrete announcement. The most difficult part of translating this model to an empirical setting involving institutional investors is that institutional holdings are only available at the end of each calendar quarter. We measure the change in ownership $(\Delta \mathrm{IH})$ by a given institution as the difference between the percent of total shares outstanding it holds at the beginning and end of the calendar quarter. Consequently, we cannot determine whether changes in institutional holdings over a quarter happened before, during, or after a news announcement. Thus, we will also add performance in the prior quarter to the specification to get an unambiguous measure of trading after firm performance is revealed to the market.

A second issue in translating the $\mathrm{KV}$ model to an empirical test is that their model assumes perfect competition among investors or that the changes in investor demands do not move prices. Market microstructure research provides evidence that block trades create price movements due to price pressure (Holthausen, et al. [1990]; Chan and Lakonishok [1993], [1995]). Because trades by institutional investors can be large enough to cause some price pressure, their private information could be impounded into price in advance of the next news 
announcement. In such as case, there could be a negative relation between private information trading and price changes around subsequent announcements. Thus, looking only at returns around news announcements could provide a biased picture of informed trading.

We examine four firm performance measures to test for private information trading. First, we examine analyst forecast errors (AFE), defined as actual earnings per share (EPS) (according to IBES) minus the last consensus analyst' forecast of EPS prior to the end of the calendar quarter, deflated by the price per share on the forecast date. Analyst forecast errors will not be mechanically affected by institutional trading, as price movements may be. ${ }^{8}$ Analyst forecasts also have the property of providing a proxy for the average level of information in the market among sophisticated market participants; whereas price can be potentially biased by naïve marginal traders (Hand [1990], Walther [1997]). The disadvantage of analyst forecast errors is that, ultimately, institutions seek price appreciation from their informed trading. Given documented biases in analyst forecasts (Abarbanell and Lehavy [2004]), their errors do not necessarily translate into price reactions. ${ }^{9}$

Second, we examine stock returns around the earnings announcement (CAR), defined as the three-day cumulative abnormal size-adjusted return in the window $(-2,0)$ around the earnings announcement. This measure most directly captures the theoretical construct in KV and has been used by prior research to test for private information trading (Ali, et al. [2004], Pinnuck [2004]). As mentioned earlier, this measure has the drawback that the return surprise around earnings announcements could be related to the degree of private information trading that has

\footnotetext{
${ }^{8}$ Although, to the extent that analysts use price changes to update their forecasts, there still may be an indirect relation between private information trading and subsequent forecast errors

${ }^{9}$ Another potential drawback is that future earnings performance could be a function of institutional ownership if corporate managers manipulate earnings based on the institutional investor clienteles (Bushee [1998]).
} 
already been impounded in price. Also, this measure only captures private information trading related to short-term earnings news.

Third, we measure firm performance using quarterly buy-and-hold returns (BHAR3), which are computed as the buy-and-hold returns for the stock less the buy-and-hold returns for the firm's size decile over the calendar quarter. This measure captures any returns to informed trading that are not realized around earnings announcements. Finally, we compute buy-and-hold returns for the year (BHAR12) subsequent to the calendar quarter of the institutional holdings change (we still use BHAR3 as the current and past performance measure in this test). This measure captures any private information trading related to longer-term news.

\subsection{Methodology}

\subsubsection{Regressions using firm-level aggregation}

The first approach we adopt to test for private information trading by institutional investors involves aggregating institution-firm-level data by firm and estimating a cross-sectional firm-level regression. For example, we aggregate all of the holdings of institutions that have held a given firm more than one year (e.g., LTHELD = 1) into a total firm-level ownership variable for this group of institutions (IH(LTHELD)). Then, we regress the change in holdings by this group of institutions on the past, current, and future performance measures: ${ }^{10}$

$$
\Delta \mathrm{IH}(\mathrm{X})_{\mathrm{jt}}=\gamma_{0}+\gamma_{1} Z_{\mathrm{jt}-1}+\gamma_{2} Z_{\mathrm{jt}}+\gamma_{3} Z_{\mathrm{jt}+1}+\varepsilon_{\mathrm{ijt}}
$$

where $\Delta \mathrm{IH}(\mathrm{X})_{\mathrm{jt}}=$ change in ownership by all institutional investors in firm $\mathrm{j}$ with private information proxy $\mathrm{X}$ equal to one; $\mathrm{X}=$ private information proxies: BANK, P\&E, IIA, GROWTH, VALUE, TRANSIENT, LARGE, BLOCK, BET, LTHELD, and INDEXP; $\mathrm{Z}_{\mathrm{jt}}=$ firm performance measure (AFE, CAR, BHAR3, or BHAR12)

\footnotetext{
${ }^{10}$ In computing changes in holdings by group, we use the value of the private information proxies at the beginning of the firm performance measurement period (see Appendix) to ensure that changes in holdings are not driven by changes in the private information proxy over the period.
} 
To mitigate biases due to cross-sectional correlation (Bernard [1987]), we estimate the above regression separately for each calendar quarter. Then, we report the mean coefficients from the quarterly regressions and perform significance tests using standard errors computed from the distribution of these coefficients (Fama and MacBeth [1973]).

This methodology is commonly used in prior research and we present results using it to enhance comparability. However, each private information proxy is treated as an independent factor, ignoring any possible correlations among factors. Thus, we adopt a second methodology which allows us to include all of the private information proxies in a multivariate framework.

\subsubsection{Hierarchical linear modeling}

Our second approach is hierarchical linear modeling (HLM), which allows estimation of multiple levels of analysis with one model (Raudenbush and Bryk [2002]). For each firm, changes in holdings by individual institutions are regressed on the private information proxies. The coefficients from the first stage are then regressed on the firm performance measures to determine how much of the sensitivity of changes in holdings to private information proxies is related to past, current, and future firm performance.

To illustrate this methodology, let $\Delta \mathrm{IH}_{\mathrm{ijt}}$ represent the change in ownership by institutional investor $\mathrm{i}$ in firm $\mathrm{j}$ at time $\mathrm{t}, \mathrm{X} 1_{\mathrm{ijt}}$ represent the vector of institution-firm-level private information proxies (LTHELD, BLOCK, BET, INDEXP), $\mathrm{X} 2_{\text {it }}$ represent the vector of institutional-level proxies (BANK, P\&E, IIA, LARGE, GROWTH, VALUE, TRANSIENT) and $\mathrm{Z}_{\mathrm{jt}}$ represent the firm performance measure (AFE, CAR, BHAR3, BHAR12) at time $t$ relative to the change in holdings. This approach can be represented by the following multi-level model:

$$
\begin{aligned}
\Delta \mathrm{IH}_{\mathrm{ijt}} & =\alpha_{\mathrm{jt}}+\beta_{1 \mathrm{jt}} \mathrm{X} 1_{\mathrm{ijt}}+\beta_{2 \mathrm{jt}} \mathrm{X} 2_{\mathrm{it}}+\varepsilon_{\mathrm{ijt}} \\
\alpha_{\mathrm{jt}} & =\gamma_{00}+\gamma_{01} \mathrm{Z}_{\mathrm{jt}-1}+\gamma_{02} \mathrm{Z}_{\mathrm{jt}}+\gamma_{03} \mathrm{Z}_{\mathrm{jt}+1}
\end{aligned}
$$




$$
\begin{aligned}
& \beta_{1 \mathrm{jt}}=\gamma_{10}+\gamma_{11} Z_{\mathrm{jt}-1}+\gamma_{12} Z_{\mathrm{jt}}+\gamma_{13} Z_{\mathrm{jt}+1} \\
& \beta_{2 \mathrm{jt}}=\gamma_{20}+\gamma_{21} Z_{\mathrm{jt}-1}+\gamma_{22} Z_{\mathrm{jt}}+\gamma_{23} Z_{\mathrm{jt}+1}
\end{aligned}
$$

The beta coefficients in equation (8a) measure how sensitive changes in institutional holdings are to the private information proxies. These coefficients are not meaningful on their own as institutional trading is only expected to be systematically related to private information proxies in those quarters when the private information calls for a trade. In such quarters, the beta coefficients will be large, and should be associated with the realized firm performance measures. Thus, the important coefficients are the gamma coefficients in equations (8c) and (8d). If these coefficients are significant in the predicted direction, it supports the argument that the institutional investor trading is sensitive to the private information proxies.

The set of equations above can be estimated using separate OLS regressions to yield unbiased coefficient estimates and, if the errors are iid, the OLS estimates are the minimum variance, unbiased estimators of the parameters (Raudenbush and Bryk [2002]). However, if the sample size or the dispersion in the variables for some firms is small, the OLS coefficients will tend to be imprecise due to finite sample bias (Raudenbush and Bryk [2002]). In such a case, substituting the equations $(8 \mathrm{~b}, 8 \mathrm{c}$, and $8 \mathrm{~d})$ into $(8 \mathrm{a})$ yields more accurate estimates:

$$
\begin{aligned}
\Delta \mathrm{IH}_{\mathrm{ijt}} & =\left(\gamma_{00}+\gamma_{01} \mathrm{Z}_{\mathrm{jt}-1}+\gamma_{02} \mathrm{Z}_{\mathrm{jt}}+\gamma_{03} \mathrm{Z}_{\mathrm{jt}+1}\right)+\left(\gamma_{10}+\gamma_{11} \mathrm{Z}_{\mathrm{jt}-1}+\gamma_{12} \mathrm{Z}_{\mathrm{jt}}+\gamma_{13} \mathrm{Z}_{\mathrm{jt}+1}\right) \mathrm{X} 1_{\mathrm{ijt}} \\
& +\left(\gamma_{20}+\gamma_{21} \mathrm{Z}_{\mathrm{jt}-1}+\gamma_{22} \mathrm{Z}_{\mathrm{jt}}+\gamma_{23} \mathrm{Z}_{\mathrm{jt}+1}\right) \mathrm{X} 2_{\mathrm{it}}+\varepsilon_{\mathrm{ijt}}
\end{aligned}
$$

Because equation (9) introduces possible dependence due to repeated firm observations, we estimate a model that includes firm-quarter fixed effects. ${ }^{11}$ After rearranging terms, our final regression specification corresponds to equation (5), which we derived from the KV model:

$$
\begin{aligned}
& \Delta \mathrm{IH}_{\mathrm{ijt}}=(\text { Firm fixed effect })_{\mathrm{jt}}+\left(\gamma_{10} \mathrm{X} 1_{\mathrm{ijt}}+\gamma_{20} \mathrm{X} 2_{\mathrm{it}}\right)+\left(\gamma_{11} \mathrm{X} 1_{\mathrm{ijt}}+\gamma_{21} \mathrm{X} 2_{\mathrm{it}}\right) \mathrm{Z}_{\mathrm{jt}-1}+ \\
& \left(\gamma_{12} \mathrm{X} 1_{\mathrm{ijt}}+\gamma_{22} \mathrm{X} 2_{\mathrm{it}}\right) \mathrm{Z}_{\mathrm{jt}}+\left(\gamma_{13} \mathrm{X} 1_{\mathrm{ijt}}+\gamma_{23} \mathrm{X} 2_{\mathrm{it}}\right) \mathrm{Z}_{\mathrm{jt}+1}+\varepsilon_{\mathrm{ijt}}
\end{aligned}
$$

\footnotetext{
${ }^{11}$ Since fixed effects models with numerous dummies are computationally intensive, we re-center the data and perform OLS to produce comparable results (Greene [2000], p.565).
} 
where $\Delta \mathrm{IH}_{\mathrm{ijt}}=$ change in ownership by institutional investor $\mathrm{i}$ in firm $\mathrm{j}$;

$\mathrm{X}_{\mathrm{ijt}}=$ vector of institution-firm-level private information proxies (LTHELD, BLOCK, BET, and INDEXP);

$\mathrm{X} 2_{\text {it }}=$ vector of fixed institutional private information proxies (BANK, P\&E, IIA, LARGE, GROWTH, VALUE, and TRANSIENT); $Z_{\mathrm{jt}}=$ firm performance measure (AFE, CAR, BHAR3, or BHAR12)

We estimate these regressions by calendar quarter and report the mean coefficients with significance tests based on Fama-MacBeth standard errors.

\section{Sample and Descriptive Statistics}

\subsection{Sample}

Our sample period spans the years 1983 to 2004, which the extent of the Thomson Financial Spectrum database. ${ }^{12}$ The Spectrum data is based on the Form 13-F information filed with the SEC, which requires institutions managing more than $\$ 100$ million in equity to file a quarterly report with the SEC of all equity holdings greater than 10,000 shares or $\$ 200,000$ in market value. We apply the following data requirements in forming our sample. First, we require all institutions to have been listed on Spectrum for at least three years so we can compute a reasonable "time held" variable for an institution's investment in a firm. Second, we require all firms to have at least one year of prior observations on Spectrum to remove any unusual effects due to IPO's. Third, we require that firms have at least 50 institutional investors in a given quarter to ensure there is sufficient cross-sectional variation in individual institution types within a firm. Fourth, we restrict the sample to December fiscal-year-end firms to facilitate matching of fiscal quarters to Spectrum calendar quarters. Finally, we require that Spectrum data can be matched to Compustat, for which we collect industry classification and firm size data. These data restrictions result in 11,664,695 institution-firm-quarter observations from Spectrum, which represents 82,601 firm-quarters.

\footnotetext{
${ }^{12}$ The data starts in 1980 , but we require at least three years of prior data
} 
We obtain stock return data from CRSP and analyst forecast data from I/B/E/S. We allow the final sample size to vary by performance measure to maximize the number of observations for each test. We have a small loss of observations for the returns measures due to missing return data or missing earnings announcements. For the analyst forecast tests, we lose about $45 \%$ of our observations due to firms not covered by $\mathrm{I} / \mathrm{B} / \mathrm{E} / \mathrm{S}$ and to the fact that quarterly forecasts are not widely available until 1985 . Final sample sizes are provided in Table 1 with the descriptive statistics for each performance metric.

\subsection{Descriptive statistics}

The first row of Table 1 shows that most quarterly changes in individual institutional investor holdings tend to be quite small in terms of percent of the total shares outstanding (mean and median change is $0.0 \%$, with a standard deviation of $0.2 \%$ ). The next set of rows provides the change in institutional holdings aggregated to the firm level. The mean (median) change in the percentage ownership for the sum of all institutions is $3.1 \%(2.5 \%)$, consistent with a timeseries increase in institutional ownership over the sample period. Of the different types of institutions, investment advisers, transient institutions, and large institutions tend to have the largest changes in ownership, as suggested by the standard deviation.

The remainder of Table 1 provides descriptive statistics for the four performance measures: analyst forecast errors (AFE), cumulative abnormal returns around earnings announcements (CAR), and buy-and-hold abnormal returns over three and twelve month periods (BHAR3 and BHAR12, respectively). ${ }^{13}$ In the general, the means for the measures are positive, but smaller than $1 \%$. The only exception is that the mean BHAR3 in the prior period is $1.5 \%$,

\footnotetext{
${ }^{13}$ Because of extreme observations, we truncate the top and bottom $1 \%$ of all performance measures based on distribution from the full Compustat population. For the price-deflated analyst forecast errors, we also remove observations where the absolute value is above 1 before this truncation. Results are quantitatively similar if we windsorize extreme observations instead of truncating and if we do not first remove extreme forecast errors.
} 
which is due to the fact that we impose a small selection bias in requiring firms to have prior, current, and future period returns.

In Table 2, we present descriptive evidence on the associations among the private information proxies. This table reports the percent of each type of institution (in columns) that also has a value of 1 for the other private information proxies (in rows). For example, the first column reports the percent of all institutions that are BANK (28.5\%), P\&E (9.5\%), and so forth. The first column is also a useful benchmark to determine whether specific types of institutions are over- or underrepresented by another private information proxy. In the rest of the table, we present the difference between the percent of institutions of a type that have the other private information proxy and the percent for all institutions. For example, the $-8.3 \%$ in the BANK column for the VALUE row indicates that $19.6 \%$ of banks follow a value strategy, which is 8.3 percentage points lower than the overall frequency of $27.9 \%$.

Panel A presents the institution-specific characteristics in the columns. Consistent with their fiduciary responsibilities, BANK and P\&E institutions tend to follow neither extreme GROWTH nor VALUE strategies, have fewer TRANSIENT institutions, more LARGE institutions, and fewer BET and INDEXP strategies. The only difference is that banks have a higher percentage of long-term holdings (LTHELD). In contrast, IIA tend to have more GROWTH and VALUE strategies, more TRANSIENT institutions, fewer LARGE and LTHELD institutions, and more BLOCK, BET, and INDEXP strategies. VALUE and GROWTH institutions are more likely to be TRANSIENT (and vice versa), and all three types are less likely to have LTHELD equal to one. LARGE institutions are more likely to have BLOCK and LTHELD strategies, and less likely to make big portfolio bets. 
Panel B presents the institution-firm-level characteristics in columns. BLOCK, BET, and LTHELD strategies tend to be highly related, suggesting that large positions are often built up over time. BET and INDEXP also tend to be related, indicating that institutions placing a big bet on a single stock tend to take bets on the other firms in that stock's industry. Overall, there is significant overlap in many of these private information proxies, indicating the importance of controlling for multiple characteristics in the empirical analysis.

\section{Results}

\subsection{Regressions using firm-level aggregation}

Table 3 presents results from regressions using firm-level aggregation of the institutional holdings based on the private information proxies (equation (7)). The first column lists the dependent variable, the next column indicates whether the coefficients in the rows pertain to past, current, or future performance measures, and the next columns represent the four different performance measures, which are estimated in separate regressions. Significance tests are twotailed and based on the standard error from the distribution of quarterly regression coefficients.

The first set of rows presents results for changes in total institutional ownership (ALL) as the dependent variable. We find that institutional ownership is positively associated with current analyst forecast errors (AFE), consistent with Lang and McNichols [1997]. Future forecast errors are insignificant, suggesting that institutional investors, as a group, do not exhibit trading based on better information than analysts. Changes in total institutional ownership are positively associated with prior and current returns around earnings announcements (CAR) and over threemonth intervals (BHAR3 and BHAR12). ${ }^{14}$ These results do not support hypothesis 1 and suggest that institutions as a group are momentum traders, buying winners and selling losers

\footnotetext{
${ }^{14}$ Recall that, for the BHAR12 regressions, prior and current returns are measured over the same three-month period as the change in institutional ownership, whereas future returns are measured over 12-month periods.
} 
after the fact. Consistent with Ali, et al. [2004], there is a positive relation between institutional trading and future earnings announcements CAR. While this positive coefficient is consistent with hypothesis 2 , the fact that the coefficients on current and past performance are also positive suggests that these results reflect a risk-based explanation (e.g., institutions buy [sell] firms with higher [lower] risk and expected returns), rather than private information trading.

The decomposition into fiduciary types reveals that both BANK and IIA institutions are similar to the total population of institutions, consistent with Ali, et al. [2004]. The negative coefficients on the buy-and-hold return measures for changes in P\&E ownership are consistent with hypothesis 1 and suggest some anticipation of current news and/or cashing out of prior profitable trading. However, if $\mathrm{P} \& \mathrm{E}$ institutions are trading based on private information, it must pertain to periods longer than one year, on average, as there is no relation between P\&E trading and future returns. Despite the fact that there is below average overlap between P\&E and VALUE, the results for the two types are similar, suggesting some overlap in trading strategies. The results for GROWTH, TRANSIENT, and LARGE institutions are also very similar to ALL institutions and to each other. Coefficients on current AFE and on the three prior and current returns measures are positive and strongly significant. Again, this body of results is not consistent with anticipating news or "cashing out" on prior informed trades; instead, it suggests momentum trading based on realized performance. However, consistent with hypothesis 2 , changes in holdings by GROWTH and TRANSIENT institutions are significantly positively related to future AFE, suggesting that these institutions have better information than analysts (for TRANSIENT institutions, this result is consistent with Ke and Petroni [2004]). For all three types of institutions, their trading is positively related to future CAR, again consistent with hypothesis 2, but negatively associated with BHAR12, suggesting that any private information 
must be related to short-term news. However, the question remains of why we do not see these institutions cashing out after trading successfully based on future CAR, making it difficult to disentangle informed trading from trading based on risk preferences. Moreover, the fact that they systematically change their holdings in response to past CAR suggests that they did not fully anticipate the news during the earnings announcement.

Changes in holdings for BLOCK and BET institutions are significantly negatively related to prior and current return performance measures, consistent with hypothesis 1 , and positively related to future BHAR12, consistent with private information trading based on returns over the subsequent 12 months. This set of results suggests that institutions taking BLOCK or BET positions are trading based on private information about return performance over the subsequent year. This is the strongest, most consistent evidence of informed trading in Table 3.

Finally, there is little evidence of significant relations between trading by INDEXP and LTHELD institutions and any of the performance measures. Changes in holdings by INDEXP institutions are positively associated with current buy-and-hold returns, but no future performance measures. Changes in holdings by LTHELD institutions are only significantly related to prior return measures.

Overall, the results most consistent with private information trading in table 3 are for institutions that hold large blocks and take big portfolio bets. These results exhibit both the trading in advance of future performance and the cashing out based on prior and current performance. While some other investor characteristics are positively related to future performance (e.g., GROWTH, TRANSIENT, LARGE), these proxies are also positively related to past and current performance, suggesting momentum or risk-based trading rather than trading 
to reverse positions taken in the past based on private information. Thus, the evidence is mixed on whether the other proxies are indicators for the superior private information.

\subsection{Results using HLM}

In Table 4, we present results from estimating the quarterly HLM regressions (equation (10)) and report the mean coefficients and two-tailed significance tests based on a standard error from the quarterly distribution of coefficients. ${ }^{15}$ We only report the coefficients on the interactions between the performance measures and private information proxies, as these represent whether an investor trades are aligned with price movements in a manner that is consistent with private information. We do not report the main effects as these merely represent the mean change in holdings for each institutional investor characteristic (conditional on the other characteristics) independent of firm performance measures. These means all tend to be small and do not provide any evidence relevant to the existence of private information trading.

The first striking piece of evidence from Table 4 is that the interactions between proxies for fiduciary type of institution (BANK, IIA, and P\&E) and performance measures are now largely insignificant once the other characteristics are included in the model. There are no significant associations with future performance measures; although the evidence of momentum (contrarian) trading by IIA (P\&E) with regards to current returns remains significant. For banks, the only significant result is a positive relation between changes in holdings and current analyst forecast errors. Thus, the fiduciary type of an institution appears to be a poor proxy for differences in private information across institutions.

Table 4 presents mixed results for the other institution-level characteristics. As in Table 3, changes in holdings by VALUE institutions are negatively associated with prior and current

\footnotetext{
${ }^{15}$ We multiply the coefficients by 100 in these regressions because the changes in percentage ownership at the individual institutional investor level tend to be quite small.
} 
return-based measures, consistent with hypothesis 1 . However, there is no evidence of a positive association between VALUE trading and future performance. In fact, changes in VALUE holdings are negatively related to future AFE and CAR, suggesting that, if VALUE investors are trading based on private information, it must be manifested in earnings or returns beyond one year. The GROWTH, TRANSIENT, and LARGE characteristics all remain significantly positively associated with prior and current return performance in the HLM model, consistent with momentum trading, but not informed trading. The positive relations between these characteristics and future CAR are only significant in the HLM model for GROWTH, suggesting that that the Ali, et al. [2004] finding is driven by growth institutions within the IIA type. Other than this result, the only evidence among these characteristics consistent with informed trading is the significant positive relation between TRANSIENT trading and future AFE.

The HLM results for the BLOCK and BET proxies are similar to the results in Table $3 .{ }^{16}$ Changes in holdings by institutions with large blocks and large portfolio bets in firms are negatively related to past and current returns, consistent with hypothesis 1 . Moreover, both proxies are positively associated with BHAR12, consistent with hypothesis 2 in regards to private information about longer-term returns. ${ }^{17}$ Thus, the evidence suggests that BLOCK and BET are fundamental proxies for private information that are not capturing some other factor.

Unlike Table 3, the results for the INDEXP now suggest private information trading consistent with hypothesis 1 . Table 4 reports a negative association between INDEXP and both prior and current BHAR3 and BHAR12, whereas these relations were either insignificant or

\footnotetext{
${ }^{16}$ The only difference from Table 3 is that BET is significantly negatively associated with future CAR. The source of this negative relation is unclear, and may indicate that informed trading by BET institutions impounds their information into price before the earnings announcement, producing a negative relation.

${ }^{17} \mathrm{We}$ also looked at future returns for six-month (BHAR6) and nine-month (BHAR9) windows. The positive relation between BET/BLOCK and BHAR6 (BHAR9) is significant at the $0.05(0.01)$ level. Thus, these institutions appear to be trading on information that will impact price beyond one-quarter ahead.
} 
positive in Table 3. In Table 2, we show that institutions taking industry bets tend to have an above-average representation of IIA and VALUE institutions. In Table 3, the results for IIA and VALUE were significant, but opposite sign, suggesting a suppressor effect when INDEXP is examined in isolation. Once IIA and VALUE are controlled for, the results suggest that INDEXP is consistent with cashing out or anticipating current return performance. Finally, LTHELD is positively associated with prior, current, and future AFE, suggesting momentum trading. None of these relations were significant in Table 3, again suggesting a suppressor effect.

Overall, the results of this section highlight the importance of controlling for multiple private information proxies in one analysis. Prior evidence that the fiduciary type of an institution is related to private information trading is likely driven by associations with more direct private information proxies. A lack of evidence that industry bets are associated with informed trading is due to a suppressor effect that is eliminated when other characteristics are controlled for. The clearest evidence of private information trading occurs with the return-based performance measures. Other than the positive association between changes in TRANSIENT and LTHELD holdings and future AFE, there is little evidence of informed trading relative to earnings surprises. Finally, the strongest evidence of private information trading is found among institutions that hold large positions in firms, either in terms of percent ownership or percent of their portfolio.

\subsection{Sensitivity analyses}

The KV model suggests that risk aversion could influence the extent to which an investor exploits their private information, but not necessarily the direction of their trade. To remove variation in trades due to risk aversion, we examine the decision to buy or sell a given stock. We define a buy/hold/sell indicator variable based on changes in holdings, with buys equal to 1 , sells 
equal to -1 , and holds equal to 0 . We then estimate equation (10) with the buy/hold/sell indicator as the dependent variable. ${ }^{18}$

The results of this analysis are similar to Table 4 with only a few exceptions (not tabled). The BLOCK proxy is no longer significantly associated with future BHAR12 with the buy/hold/sell indicator. Thus, the magnitude of the trade is important for detecting informed trading by BLOCK institutions, whereas it is not important for BET institutions. The relation between TRANSIENT trading and future AFE is also no longer significant with the indicator variable, suggesting that magnitude matters here as well. Finally, there are no meaningful differences in results for fiduciary type, indicating that the lack of informed trading results is not due to risk aversion effects, but rather to fiduciary type failing to proxy for private information trading incremental to the other characteristics in the model.

We also estimated the HLM model in Table 4 with the sample partitioned into small, medium, and large firms, based on treciles of market value of equity (not tabled). Private information trading is more likely to be present in smaller firms, as large firms often have rich public information environments (e.g., more analyst following, more conference calls) and less opportunity for informed trading. We find that the pattern of informed trading results for BLOCK (BET) is driven by the small (small and medium) firms, consistent with the higher likelihood of finding informed trading among small firms. In contrast, the "cashing out" behavior of VALUE intuitions in Table 4 is equally strong across all size subsamples, making it less likely that this result reflects informed trading.

\footnotetext{
${ }^{18}$ This analysis is done using a linear probability model (OLS) rather than a multinomial logit because computing fixed effects in logistic models is not as straightforward as de-meaning linear models and require considerable computing time given the number of observations. The primary advantages of logit estimation are that the standard errors are less susceptible to heteroskedasticity and the probabilities will be bounded between 0 and 1 (Greene [2000]). Because we use Fama-MacBeth t-statistics, heteroskedasticity in any single quarterly model will not be a concern since the estimates will still be unbiased. We also do not use the predicted values, so values that exceed the reasonable bounds for probabilities are not an issue.
} 
5.4 Interactions among private information proxies

To provide additional evidence on the specific characteristics associated with informed trading, we interact some of the institution-firm-level proxies with the other proxies for private information. First, we interact the indicator for whether an institution has a large position in a portfolio firm (BLOCK and BET) with the other characteristics. For parsimony, we combine the two proxies to create an indicator variable that equals 1 if BLOCK or BET equals 1 , and zero otherwise. This analysis will reveal whether the strong evidence of informed trading based on BET and BLOCK is concentrated among other characteristics or is a more general result. Moreover, conditioning on the presence of a large stake in a given stock provides a more powerful test for hypothesis 1. If holding a BLOCK or BET position entails costs due to lack of diversification, then a reduction in the expected benefits to holding that position (i.e., the realization of the private information) would create incentives to reduce the position immediately, rather than continue to hold an abnormally large position.

Table 5 provides the results of the HLM estimation of equation (10) with all private information proxies (except BLOCK and BET) interacted with the indicator variable for whether the institution has a BLOCK or BET in place for a given firm. The table shows that the significant informed trading results observed for BLOCK and BET characteristics in Table 4 are concentrated in IIA and LARGE institutions that have BLOCK or BET equal to $1 .{ }^{19}$ Thus, private information trading is most evident when large positions in firms are taken by investment advisers, which have limited fiduciary responsibilities and lower risk aversion, and by large institutions, which have greater resources and potentially more access to management.

\footnotetext{
${ }^{19} \mathrm{P} \& \mathrm{E}$ institutions that have a BLOCK or BET also exhibit the same results as BLOCK and BET except there is no significant relation with future performance. Thus, any private information trading by $\mathrm{P} \& \mathrm{E}$ institutions must relate to performance more than one-year in the future.
} 
Table 5 also shows that the momentum trading results for GROWTH, TRANSIENT, and LARGE institutions are concentrated in small positions $(\mathrm{BET}$ and BLOCK $=0) .{ }^{20}$ Interestingly, LARGE institutions with small positions in firms are simply momentum trading, whereas large positions are taken when the institutions has private information. The results for VALUE institutions indicate evidence of contrarian trading in response to prior and current return performance regardless of whether the fund has a large position or not. Finally, institutions with holdings in the firm of less than a year (LTHELD) and small positions exhibit evidence consistent with informed trading for BHAR12. This result indicates that institutions are less likely to take large positions based on private information if they have held a stock for more than a year.

Next, we interact the indicator for whether an institution has held a position for a year (LTHELD) with the other proxies. Although there is no evidence that LTHELD alone proxies for informed trading, this analysis will provide additional evidence on whether contrarian trading based on prior and current news reflects prior private information or some other explanation. In Table 6, we interact all of the private information proxies (except LTHELD) with LTHELD and estimate equation (10). For BLOCK and BET, the informed trading results are only found for large positions held less than one year. These results suggest that some institutions with private information take a large BLOCK or BET position in an undervalued firm, hold it more than one quarter but less than a year, and then cash out the position when the positive returns are realized (or, alternatively, before negative returns are realized).

Table 6 also shows that the contrarian trading with respect to prior and current return performance for P\&E, VALUE, and INDEXP is only present in positions that have been held for

\footnotetext{
${ }^{20}$ When transient investors have large positions, there is a negative relation with future CAR. It is possible that this result could reflect informed trading if the block trades of informed transient investors causes price to impound the private information prior to the earnings announcement.
} 
less than one year. Again, these results suggest that private information trading results in shortterm positions; however, the lack of evidence of trading in advance of future performance makes it unclear whether these results reflect informed trading or some other explanation.

Finally, Table 6 shows that the momentum trading by GROWTH, TRANSIENT, and LARGE institutions is present in positions held less than one year. In long-term positions, GROWTH and TRANSIENT institutions exhibit contrarian trading with respect to prior and current performance, consistent with hypothesis 1. Interestingly, for BHAR3 and BHAR12, there is also evidence consistent with hypothesis 2 for GROWTH institutions holding a position longer than one year. This result suggests that once a growth institution has held a firm for more than a year, it has gained a private information advantage that allows it to execute informed trading based on future returns.

\section{Conclusion}

In this paper, we contribute to the existing literature on informed trading by institutional investors by analyzing new proxies for the conditions in which an investor may have private information, by employing a HLM methodology that controls for the overlap across investor classifications, and by examining both the creation and liquidation of positions consistent with information-based trading. We find that changes in ownership by institutions that have created a large position in a specific firm (both in terms of percent ownership and percent of its portfolio) are consistent with trading based on private information. Other previously-documented proxies for private information produce results that are more consistent with momentum or risk-based trading (e.g., transient institutions and preferences for growth) or that are insignificant in the

presence of the other proxies (e.g., banks, investment advisers). The clearest evidence of private information trading occurs with the return-based performance measures; there is limited 
evidence of informed trading related to earnings-based measures (e.g., analyst forecast errors). Finally, tests for interactions among private information proxies reveal that informed trading is most evident when large positions in firms are newly initiated and when they are taken by investment advisers (which have limited fiduciary responsibilities) and by large institutions (which have greater resources and potentially more access to management).

The results of this paper are subject to a number of limitations. The mismatch between the quarterly institutional holdings data and daily or intra-day price movements reduces the power of the tests to identify informed trading. In addition, to implement our HLM methodology, we make a number of research design choices, such as only examining firms with at least 50 institutional owners and only examining institutions with at least three years of data, that eliminate smaller firms and institutions for which informed trading may be more prevalent. Thus, our results may understate the amount of informed trading. However, we do find that examining proxies that measure an institution's investment in each portfolio firm yields enough power to detect informed trading despite the timing mismatch. We also demonstrate the potential biases of failing to control for multiple institutional investor characteristics in the same model and failing to interpret the signs on both current and future performance measures. Because private information is difficult to measure, we suggest that future work employ the research design and HLM methodology of this paper to further examine the extent to which institutions possess private information before announcements and/or a superior advantage in interpreting public disclosures. 


\section{References}

Abarbanell, J., B. Bushee, and J. Raedy. "Institutional Investor Preferences and Price Pressure: The Case of Corporate Spin-Offs.” Journal of Business 76 (2003): 233-261.

Abarbanell, J. and R. Lehavy. "Biased Forecasts or Biased Earnings? The Role of Reported Earnings in Explaining Apparent Bias and Over/Underreaction in Analysts' Earnings Forecasts." Journal of Accounting and Economics 36 (2003): 105-146.

Ali, A., C. Durtschi, B. Lev, and M. Trombley. "Changes in Institutional Ownership and Subsequent Earnings Announcement Abnormal Returns." Journal of Accounting, Auditing, and Finance 19 (2004): 221-248.

Ataise, R. and L. Bamber. "Trading Volume Reactions to Annual Accounting Earnings Announcements: The Incremental Role of Predisclosure Information Asymmetry.” Journal of Accounting and Economics 17 (1994): 309-329

Badrinath, S.G. and S. Wahal. "Momentum Trading by Institutions.” Journal of Finance 57 (2002): 2449-2478.

Bamber, L. O. Barron, and T. Stober. "Trading Volume and Different Aspects of Disagreement Coincident With Earnings Announcements." The Accounting Review 72 (1997): 575-597.

Beaver, W. "The Information Content of Annual Earnings Announcements." Journal of Accounting Research 6 (1968): 67-92.

Bernard, V. "Cross-Sectional Dependence and Problems in Inference in Market-Based Accounting Research.” Journal of Accounting Research 25 (1987):1-48.

Bernard, V. and J. Thomas. "Evidence that Stock Prices Do Not Fully Reflect the Implications of Current Earnings for Future Earnings." Journal of Accounting and Economics 13 (1990): 305-340.

Brown, S. and W. Goetzmann. "Performance Persistence." Journal of Finance 50 (1995): 679698.

Bushee, B. "The Influence of Institutional Investors on Myopic R\&D Investment Behavior." The Accounting Review 73 (1998): 305-333.

Bushee, B. "Do Institutional Investors Prefer Near-Term Earnings over Long-Run Value?" Contemporary Accounting Research 18 (2001): 207-46.

Bushee, B., and C. Noe. "Corporate Disclosure Practices, Institutional Investors, and Stock Return Volatility." Journal of Accounting Research 38 (2000): 171-202. 
Chan, L. and J. Lakonishok. "Institutional Trades and Intraday Stock Price Behavior." Journal of Financial Economics 33 (1993): 173-199.

Chan, L. and J. Lakonishok. "The Behavior of Stock Prices around Institutional Trades.” Journal of Finance 50 (1995): 1147-1174.

Del Guercio, D. "The Distorting Effect of the Prudent Man Law of Institutional Equity Investments." Journal of Financial Economics 40 (1996): 31-62.

Dennis, P. and J. Weston. "Who's Informed? An Analysis of Stock Ownership and Informed Trading" Working paper, University of Virginia, 2001.

Fama, E. and J. MacBeth "Risk, Return, and Equilibrium: Empirical Tests." Journal of Political Economy 81 (1973): 607-636.

Greene, W. Econometric Analysis, 4th edition. Upper Saddle River, NJ: Prentice-Hall, 2000.

Hand, J. "A Test of the Extended Functional Fixation Hypothesis." The Accounting Review 65 (1990): 740-763.

Holthausen, R., R. Leftwich, and D. Mayers. "Large-Block Transactions, the Speed of Response, and Temporary and Permanent Stock-Price Effects." Journal of Financial Economics 26 (1990): 71-95.

Hotchkiss, E. and D. Strickland. "Does Shareholder Composition Matter? Evidence from the Market Reaction to Corporate Earnings Announcements." Journal of Finance 58 (2003): 1469-1498.

Jagedessh, N. and S. Titman. "Returns to Buying Winners and Selling Losers: Implications for Stock Market Efficiency." Journal of Finance 48 (1993): 65-91.

Jensen, M. "The Performance of Mutual Funds in the Period 1945-64." Journal of Finance (1968): 389-416.

Jiambalvo, J. S. Rajgopal, M. Venkatachalam. "Institutional Ownership and the Extent to which Stock Prices Reflect Future Earnings." Contemporary Accounting Research 19 (2002): 117145.

Lang, M. and M. McNichols. "Institutional Trading and Corporate Performance." Working paper, Stanford University, 1997.

Ke, B. and K. Petroni. "How Informed are Actively Trading Institutional Investors? Evidence from Their Trading Behavior Before a Break in a String of Consecutive Earnings Increases." Journal of Accounting Research 42 (2004): 895-927. 
Ke, B. and S. Ramalingegowda. "The Effect of Investment Horizon on Institutional Investors' Incentives to Acquire Private Information on Long-Term Earnings.” Working Paper, Penn St. University, 2005.

Kim, O. and R. Verrecchia. "Market Reactions to Anticipated Announcements." Journal of Financial Economics 30 (1991): 273-309.

Kim, O. and R. Verrecchia. "Pre-Announcement and Event-Period Private Information." Journal of Accounting and Economics 24 (1997): 395-419.

O’Brien, P., and R. Bhushan. "Analyst Following and Institutional Ownership." Journal of Accounting Research 28 (1990): 55-76.

Pinnuck, M. "What is the Abnormal Return Performance of Mutual Funds due to Earnings Information?" Working Paper, University of Melbourne, 2004.

Piotroski J. and D. Roulstone. "The Influence of Analysts, Institutional Investors, and Insiders on the Incorporation of Market, Industry, and Firm-Specific Information into Stock Prices." The Accounting Review 79 (2003): 1119-1151.

Raudenbush, S. and A. Bryk. Hierarchical Linear Models: Applications and Data Analysis Methods. $2^{\text {nd }}$ edition, Sage Publications, 2002.

Utama, S. and W. Cready. "Institutional Ownership, Differential Predisclosure Precision and Trading Volume at Announcement Dates." Journal of Accounting and Economics 24 (1997): 129-150.

Walther, B. "Investor Sophistication and Market Earning Expectations." Journal of Accounting Research 35 (1997): 157-179. 


\section{Appendix}

Variable Definitions and Timeline

Panel A: Variable definitions

\begin{tabular}{ll} 
Variable & Definition \\
\cline { 2 - 2 } $\begin{array}{l}\Delta \mathrm{IH}_{\mathrm{jt}} \\
\text { Performance Proxies }\left(\mathrm{Z}_{\mathrm{jt}-1}, \underline{\mathrm{Z}}_{\mathrm{j} \mathrm{t}} \mathrm{Z}_{\mathrm{jt}+1}\right)\end{array}$ \\
$\begin{array}{l}\text { Actual earnings per share (EPS) (according to IBES) minus the last consensus analyst' forecast } \\
\text { of EPS prior to prior to the end of the calendar quarter, deflated by the price per share on the } \\
\text { forecast date. }\end{array}$ \\
$\begin{array}{l}\text { Three-day cumulative abnormal size-adjusted return in the window }(-2,0) \text { around the earnings } \\
\text { announcement. }\end{array}$ \\
BAR & $\begin{array}{l}\text { Buy-and-hold returns for the stock less the buy-and-hold returns for the firm's size decile over } \\
\text { the calendar quarter. }\end{array}$ \\
BHAR3 & $\begin{array}{l}\text { Current and past returns are the same as the variables in the BHAR3 regressions, but future } \\
\text { performance is measured over the following } 12 \text { month periods. }\end{array}$
\end{tabular}

$\underline{\text { Institution-level }\left(\mathrm{X}_{2 \mathrm{i}}\right) \text { private information proxies }}$

BANK An indicator variable equal to 1 if the institution is classified as a bank based on the classification scheme used in Abarbanell et al. (2003)

P\&E An indicator variable equal to 1 if the institution is classified as a Pension/Endowment based on the classification scheme used in Abarbanell et al. (2003)

IIA An indicator variable equal to 1 if the institution is classified as a Independent Investment advisor based on the classification scheme used in Abarbanell et al. (2003)

VALUE An indicator variable equal to 1 if the institution is classified as a value investor based on the classification scheme used in Abarbanell et al. (2003)

GROWTH An indicator variable equal to 1 if the institution is classified as a growth investor based on the classification scheme used in Abarbanell et al. (2003)

TRANSIENT An indicator variable equal to 1 if the institution is classified as a transient based on the classification scheme used in Bushee 2001

LARGE An indicator variable equal to 1 if the market value of assets managed by the institution is in the top quintile of all institutions in a given calendar quarter.

$\underline{\text { Institution-firm-level }\left(\mathrm{X}_{1 \mathrm{ij}}\right) \text { private information proxies }}$

LTHELD An indicator variable equal to 1 if the institution has held the stock for four consecutive quarters as of time $\mathrm{t}-2$.

BLOCK An indicator variable equal to 1 if the percent of a firm held by an institution is in the top quintile of all institutions that own shares in that firm.

BET An indicator variable equal to 1 if the proportion of an institution's portfolio (based on market value) in a given firm is in the top quintile of all institutions that own shares in that firm. An indicator variable equal to 1 if the proportion of an institution's portfolio (based on market INDEXP value) in a firm's 2-digit SIC code is in the top quintile of all institutions that own shares in that firm. 
Appendix (continued)

Variable Definitions and Timeline

Panel B: Timeline for variable measurement

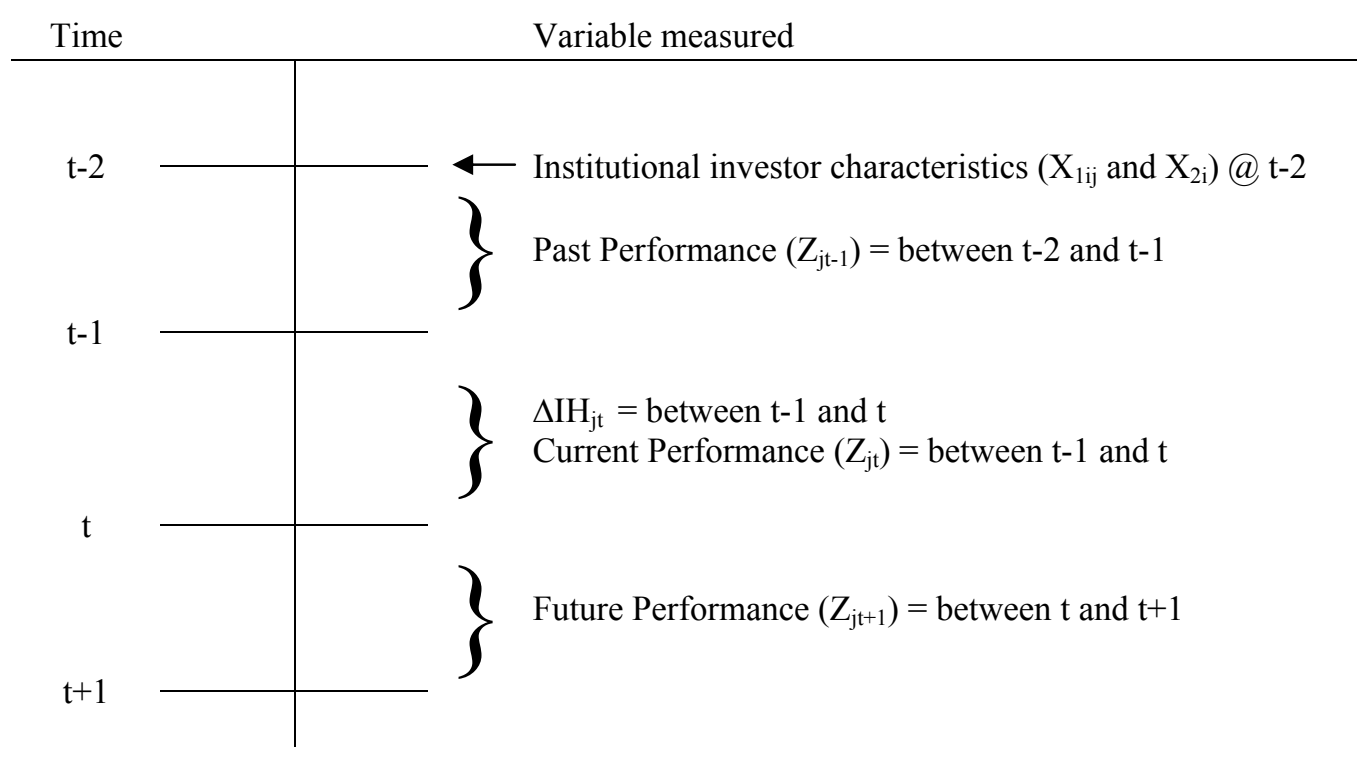


TABLE 1

Descriptive Statistics

\begin{tabular}{|c|c|c|c|c|c|c|}
\hline Variable & $\mathrm{N}$ & Mean & $\begin{array}{l}\text { Standard } \\
\text { Deviation }\end{array}$ & Q1 & Median & Q3 \\
\hline $\begin{array}{l}\text { Change in ownership by an } \\
\text { individual institution }\end{array}$ & $11,664,695$ & 0.000 & 0.002 & 0.000 & 0.000 & 0.000 \\
\hline \multicolumn{7}{|l|}{$\Delta$ total ownership by: } \\
\hline All Institutions & 82,601 & 0.031 & 0.032 & 0.010 & 0.025 & 0.045 \\
\hline BANK & 82,601 & 0.005 & 0.010 & -0.001 & 0.004 & 0.010 \\
\hline $\mathrm{P} \& \mathrm{E}$ & 82,601 & 0.003 & 0.005 & 0.000 & 0.002 & 0.005 \\
\hline IIA & 82,601 & 0.021 & 0.026 & 0.004 & 0.016 & 0.032 \\
\hline VALUE & 82,601 & 0.009 & 0.014 & 0.000 & 0.007 & 0.016 \\
\hline GROWTH & 82,601 & 0.008 & 0.015 & -0.001 & 0.004 & 0.013 \\
\hline TRANSIENT & 82,601 & 0.014 & 0.021 & 0.001 & 0.009 & 0.022 \\
\hline LARGE & 82,601 & 0.023 & 0.028 & 0.005 & 0.018 & 0.036 \\
\hline BLOCK & 82,601 & -0.005 & 0.018 & -0.014 & -0.004 & 0.005 \\
\hline BET & 82,601 & -0.006 & 0.015 & -0.013 & -0.005 & 0.002 \\
\hline INDEXP & 82,601 & 0.005 & 0.013 & -0.002 & 0.003 & 0.011 \\
\hline LTHELD & 82,601 & -0.001 & 0.018 & -0.010 & 0.000 & 0.009 \\
\hline \multicolumn{7}{|l|}{ AFE sample } \\
\hline Past performance & 42,119 & 0.004 & 0.060 & -0.001 & 0.000 & 0.001 \\
\hline Current performance & 42,119 & 0.004 & 0.063 & -0.001 & 0.000 & 0.001 \\
\hline Future performance & 42,119 & 0.003 & 0.069 & -0.001 & 0.000 & 0.001 \\
\hline \multicolumn{7}{|l|}{ CAR sample } \\
\hline Past performance & 76,684 & 0.004 & 0.048 & -0.020 & 0.002 & 0.026 \\
\hline Current performance & 76,684 & 0.003 & 0.048 & -0.021 & 0.002 & 0.026 \\
\hline Future performance & 76,684 & 0.003 & 0.048 & -0.021 & 0.001 & 0.025 \\
\hline \multicolumn{7}{|l|}{ BHAR3 sample } \\
\hline Past performance & 80,526 & 0.015 & 0.182 & -0.086 & 0.004 & 0.101 \\
\hline Current performance & 80,526 & 0.010 & 0.180 & -0.089 & 0.001 & 0.097 \\
\hline Future performance & 80,526 & 0.002 & 0.176 & -0.091 & 0.000 & 0.088 \\
\hline \multicolumn{7}{|l|}{ BHAR12 sample } \\
\hline Past performance & 79,867 & 0.015 & 0.182 & -0.086 & 0.004 & 0.101 \\
\hline Current performance & 79,867 & 0.009 & 0.180 & -0.089 & 0.001 & 0.097 \\
\hline Future performance & 79,867 & 0.002 & 0.379 & -0.199 & 0.000 & 0.162 \\
\hline
\end{tabular}

This table presents the descriptive statistics for the change in ownership and performance variables. The quartile descriptive statistics for the change in ownership by an individual institution is the average of quartiles that are calculated quarterly because of difficulty calculating the quartiles with a large number of observations. The total change in ownership by institutions of a given type is the aggregate change in ownership in a given firm-quarter by institutions with a given characteristic. All performance proxies are measured at the firm-quarter level. Variable definitions are given in panel A of the Appendix. 
TABLE 2

Associations among Private Information Proxies

\begin{tabular}{|c|c|c|c|c|c|c|c|c|}
\hline \multicolumn{9}{|c|}{ Panel A: Institution-specific characteristics } \\
\hline Characteristic & ALL & BANK & P\&E & IIA & VALUE & GROWTH & TRANSIENT & LARGE \\
\hline BANK & $28.5 \%$ & & & & $-8.4 \%$ & $-10.7 \%$ & $-17.9 \%$ & $1.1 \%$ \\
\hline P\&E & $9.5 \%$ & & & & $-0.7 \%$ & $-3.7 \%$ & $-3.5 \%$ & $1.0 \%$ \\
\hline IIA & $52.9 \%$ & & & & $8.4 \%$ & $17.8 \%$ & $22.3 \%$ & $-3.3 \%$ \\
\hline VALUE & $27.9 \%$ & $-8.3 \%$ & $-2.0 \%$ & $4.4 \%$ & & & $2.9 \%$ & $-2.6 \%$ \\
\hline GROWTH & $18.9 \%$ & $-7.1 \%$ & $-7.4 \%$ & $6.4 \%$ & & & $6.2 \%$ & $-1.5 \%$ \\
\hline TRANSIENT & $31.5 \%$ & $-19.8 \%$ & $-11.6 \%$ & $13.3 \%$ & $3.3 \%$ & $10.3 \%$ & & $0.8 \%$ \\
\hline LARGE & $58.7 \%$ & $2.2 \%$ & $5.9 \%$ & $-3.6 \%$ & $-5.5 \%$ & $-4.7 \%$ & $1.5 \%$ & \\
\hline BLOCK & $19.9 \%$ & $-2.0 \%$ & $-0.1 \%$ & $0.9 \%$ & $0.0 \%$ & $-0.8 \%$ & $-2.2 \%$ & $9.3 \%$ \\
\hline BET & $19.9 \%$ & $-8.6 \%$ & $-4.5 \%$ & $6.2 \%$ & $5.1 \%$ & $4.5 \%$ & $0.7 \%$ & $-7.0 \%$ \\
\hline INDEXP & $19.8 \%$ & $-3.0 \%$ & $-5.6 \%$ & $3.2 \%$ & $4.4 \%$ & $1.4 \%$ & $-0.1 \%$ & $-1.4 \%$ \\
\hline LTHELD & $59.6 \%$ & $7.7 \%$ & $-0.2 \%$ & $-5.4 \%$ & $-3.6 \%$ & $-6.6 \%$ & $-14.6 \%$ & $4.5 \%$ \\
\hline
\end{tabular}

Panel B: Institution-firm match characteristics

\begin{tabular}{|c|c|c|c|c|c|}
\hline \multirow[b]{2}{*}{ Characteristic } & \multirow[b]{2}{*}{ ALL } & \multicolumn{4}{|c|}{ Difference between percent for type of institution and percent for ALL } \\
\hline & & BLOCK & BET & INDEXP & LTHELD \\
\hline BANK & $28.5 \%$ & $-2.8 \%$ & $-12.3 \%$ & $-4.3 \%$ & $3.7 \%$ \\
\hline P\&E & $9.5 \%$ & $0.0 \%$ & $-2.1 \%$ & $-2.7 \%$ & $0.0 \%$ \\
\hline IIA & $52.9 \%$ & $2.3 \%$ & $16.5 \%$ & $8.6 \%$ & $-4.8 \%$ \\
\hline VALUE & $27.9 \%$ & $-0.1 \%$ & $7.2 \%$ & $6.2 \%$ & $-1.7 \%$ \\
\hline GROWTH & $18.9 \%$ & $-0.7 \%$ & $4.3 \%$ & $1.4 \%$ & $-2.1 \%$ \\
\hline TRANSIENT & $31.5 \%$ & $-3.4 \%$ & $1.1 \%$ & $-0.1 \%$ & $-7.7 \%$ \\
\hline LARGE & $58.7 \%$ & $27.6 \%$ & $-20.8 \%$ & $-4.3 \%$ & $4.5 \%$ \\
\hline BLOCK & $19.9 \%$ & & $25.5 \%$ & $4.6 \%$ & $7.5 \%$ \\
\hline BET & $19.9 \%$ & $25.5 \%$ & & $11.0 \%$ & $4.0 \%$ \\
\hline INDEXP & $19.8 \%$ & $4.6 \%$ & $11.0 \%$ & & $0.7 \%$ \\
\hline LTHELD & $59.6 \%$ & $22.5 \%$ & $12.0 \%$ & $2.1 \%$ & \\
\hline
\end{tabular}

This table provides descriptive statistics on the overlap among various institutional investor classifications. Variable definitions are given in panel A of the Appendix. The values in each cell report the percent of institutions of a given type (the column label) that are also classified as another characteristic (the row label), less the percent of all institutions that are classified as that characteristic (the ALL column). Panel A presents institutional investor characteristics that are constant across all of a given institution's holdings. Panel B presents institutional investor characteristics that reflect the relation between a given institution and particular firms in its portfolio. All calculations are based on the sample of 82,601 firm-quarters. 
TABLE 3

Regressions of the Change in Institutional Holdings Aggregated by Private Information Proxies on Performance Measures

\begin{tabular}{|c|c|c|c|c|c|}
\hline \multirow{2}{*}{$\begin{array}{l}\text { Dependent } \\
\text { Variable }\end{array}$} & \multirow[b]{2}{*}{ Perf. Period } & \multicolumn{4}{|c|}{ Performance Measure } \\
\hline & & AFE & CAR & BHAR3 & BHAR12 \\
\hline \multirow{3}{*}{ ALL } & Past & $0.052 *$ & $0.024 * *$ & $0.010 * *$ & 0.010 ** \\
\hline & Current & $0.110^{* *}$ & $0.034 * *$ & $0.022 * *$ & $0.022 * *$ \\
\hline & Future & 0.019 & $0.008^{*}$ & 0.000 & $-0.002 *$ \\
\hline \multirow[t]{3}{*}{ BANK } & Past & $0.025^{* *}$ & $0.007 * *$ & $0.003^{* *}$ & $0.003^{* *}$ \\
\hline & Current & $0.063^{* *}$ & $0.006^{* *}$ & $0.003 * *$ & $0.003 * *$ \\
\hline & Future & 0.004 & 0.001 & 0.000 & $0.000^{*}$ \\
\hline \multirow[t]{3}{*}{$P \& E$} & Past & 0.002 & 0.000 & $-0.001^{*}$ & $-0.001 *$ \\
\hline & Current & -0.003 & -0.001 & $-0.001 * *$ & $-0.001 * *$ \\
\hline & Future & -0.006 & 0.001 & 0.000 & 0.000 \\
\hline \multirow[t]{3}{*}{ IIA } & Past & 0.008 & $0.014^{* *}$ & $0.006^{* *}$ & $0.007 * *$ \\
\hline & Current & 0.039 & $0.025 * *$ & $0.019 * *$ & $0.019 * *$ \\
\hline & Future & 0.023 & $0.007^{* *}$ & 0.000 & -0.001 \\
\hline \multirow[t]{3}{*}{ VALUE } & Past & 0.000 & $-0.008 * *$ & $-0.009 * *$ & $-0.009^{* *}$ \\
\hline & Current & 0.006 & $-0.012 * *$ & $-0.010 * *$ & $-0.010^{* *}$ \\
\hline & Future & $-0.048 * *$ & -0.001 & 0.000 & 0.000 \\
\hline \multirow[t]{3}{*}{ GROWTH } & Past & 0.024 & $0.021 * *$ & $0.016^{* *}$ & $0.016^{* *}$ \\
\hline & Current & $0.067 * *$ & $0.035^{* *}$ & $0.023 * *$ & $0.024 * *$ \\
\hline & Future & $0.045^{* *}$ & $0.006^{* *}$ & 0.000 & $-0.001 *$ \\
\hline \multirow[t]{3}{*}{ TRANSIENT } & Past & $0.033^{*}$ & $0.022^{* *}$ & $0.015^{* *}$ & $0.015^{* *}$ \\
\hline & Current & $0.123^{* *}$ & $0.037 * *$ & $0.023 * *$ & $0.023^{* *}$ \\
\hline & Future & $0.048^{* *}$ & $0.005^{*}$ & 0.000 & $-0.001 * *$ \\
\hline \multirow[t]{3}{*}{ LARGE } & Past & $0.038^{*}$ & $0.020^{* *}$ & $0.009 * *$ & $0.010 * *$ \\
\hline & Current & $0.120^{* *}$ & $0.030^{* *}$ & $0.019 * *$ & $0.020^{* *}$ \\
\hline & Future & 0.021 & $0.008^{* *}$ & -0.001 & $-0.001 *$ \\
\hline \multirow[t]{3}{*}{ BLOCK } & Past & $-0.041 * *$ & $-0.009 * *$ & $-0.009 * *$ & $-0.009 * *$ \\
\hline & Current & -0.017 & $-0.009 * *$ & $-0.005 * *$ & $-0.005 * *$ \\
\hline & Future & -0.001 & 0.000 & 0.001 & $0.001 * *$ \\
\hline \multirow[t]{3}{*}{ BET } & Past & $-0.020^{*}$ & $-0.010^{* *}$ & $-0.010 * *$ & $-0.010 * *$ \\
\hline & Current & $-0.053 * *$ & $-0.016^{* *}$ & $-0.009 * *$ & $-0.009 * *$ \\
\hline & Future & -0.009 & -0.001 & 0.001 & $0.001 * *$ \\
\hline \multirow[t]{3}{*}{ INDEXP } & Past & 0.006 & 0.002 & 0.000 & 0.000 \\
\hline & Current & -0.008 & 0.002 & $0.002 * *$ & $0.002 * *$ \\
\hline & Future & -0.010 & 0.001 & 0.000 & 0.000 \\
\hline \multirow[t]{3}{*}{ LTHELD } & Past & -0.014 & $-0.005 * *$ & $-0.006^{* *}$ & $-0.006^{* *}$ \\
\hline & Current & 0.018 & -0.003 & -0.001 & -0.001 \\
\hline & Future & -0.021 & 0.003 & 0.001 & 0.000 \\
\hline
\end{tabular}

*, ** Significantly different from zero at the $0.05,0.01$ level, respectively, using a two tailed test.

This table reports the results of OLS regressions where the dependent variable is the change in ownership for a given type of institution aggregated at the firm-quarter level. These changes are regressed on past, current, and future performance measures. We report the average regression coefficient from quarterly regressions with significance tests based on Fama-MacBeth t-statistics. There are 79, 87, 87, and 84 quarterly regressions for AFE, CAR, BHAR3, and BHAR12, respectively. The label in the Dependent Variable column indicates the type of institution whose holdings are aggregated and the column labels indicate the definition of performance measure for a given regression. Intercepts are estimated, but not reported. Variable definitions are given in panel A of the Appendix. 
TABLE 4

HLM Regressions of the Change in Institutional Holdings on Performance Measures Interacted with Private Information Proxies

\begin{tabular}{|c|c|c|c|c|c|}
\hline \multicolumn{2}{|c|}{ Interactions } & \multicolumn{4}{|c|}{ Performance Measure } \\
\hline Characteristic & Perf. Period & AFE & CAR & BHAR3 & BHAR12 \\
\hline BANK & $\begin{array}{l}\text { Past } \\
\text { Current } \\
\text { Future }\end{array}$ & $\begin{array}{l}-0.059 \\
0.239 * * \\
0.094\end{array}$ & $\begin{array}{r}-0.008 \\
0.001 \\
0.007\end{array}$ & $\begin{array}{l}0.003 \\
0.001 \\
0.000\end{array}$ & $\begin{array}{l}0.004 \\
0.001 \\
0.000\end{array}$ \\
\hline $\mathrm{P} \& \mathrm{E}$ & $\begin{array}{l}\text { Past } \\
\text { Current } \\
\text { Future }\end{array}$ & $\begin{array}{r}-0.080 \\
0.015 \\
0.007\end{array}$ & $\begin{array}{c}-0.017^{*} \\
-0.009 \\
0.015\end{array}$ & $\begin{array}{c}-0.003 \\
-0.007^{*} \\
0.001\end{array}$ & $\begin{array}{l}-0.003 \\
-0.008^{*} \\
-0.002\end{array}$ \\
\hline IIA & $\begin{array}{l}\text { Past } \\
\text { Current } \\
\text { Future }\end{array}$ & $\begin{array}{l}-0.224^{* *} \\
-0.124 \\
-0.020\end{array}$ & $\begin{array}{r}-0.015 \\
0.001 \\
0.010\end{array}$ & $\begin{array}{l}-0.009^{* *} \\
0.011^{* *} \\
0.000\end{array}$ & $\begin{array}{c}-0.010^{* *} \\
0.010^{* *} \\
-0.001\end{array}$ \\
\hline VALUE & $\begin{array}{l}\text { Past } \\
\text { Current } \\
\text { Future }\end{array}$ & $\begin{array}{l}-0.061 \\
-0.005 \\
-0.231 * *\end{array}$ & $\begin{array}{l}-0.036^{* *} \\
-0.050^{* *} \\
-0.009\end{array}$ & $\begin{array}{l}-0.028 * * \\
-0.044 * * \\
0.000\end{array}$ & $\begin{array}{c}-0.029 * * \\
-0.044 * * \\
0.001\end{array}$ \\
\hline GROWTH & $\begin{array}{l}\text { Past } \\
\text { Current } \\
\text { Future }\end{array}$ & $\begin{array}{l}0.080 \\
0.230^{* *} \\
0.113\end{array}$ & $\begin{array}{l}0.051 * * \\
0.112^{* *} \\
0.015^{*}\end{array}$ & $\begin{array}{l}0.053 * * \\
0.070 * * \\
0.001\end{array}$ & $\begin{array}{l}0.055^{* *} \\
0.071 * * \\
-0.002\end{array}$ \\
\hline TRANSIENT & $\begin{array}{l}\text { Past } \\
\text { Current } \\
\text { Future }\end{array}$ & $\begin{array}{l}0.032 \\
0.528 * * \\
0.297 * *\end{array}$ & $\begin{array}{l}0.043 * * \\
0.087^{*} * \\
0.005\end{array}$ & $\begin{array}{l}0.042 * * \\
0.059 * * \\
0.000\end{array}$ & $\begin{array}{l}0.043 * * \\
0.062 * * \\
-0.001\end{array}$ \\
\hline LARGE & $\begin{array}{l}\text { Past } \\
\text { Current } \\
\text { Future }\end{array}$ & $\begin{array}{l}0.084 \\
0.179^{* *} \\
0.084\end{array}$ & $\begin{array}{l}0.013^{*} \\
0.032^{* *} \\
0.007\end{array}$ & $\begin{array}{l}0.014^{* *} \\
0.025^{* *} \\
0.000\end{array}$ & $\begin{array}{l}0.014^{* *} \\
0.026^{* *} \\
0.000\end{array}$ \\
\hline BLOCK & $\begin{array}{l}\text { Past } \\
\text { Current } \\
\text { Future }\end{array}$ & $\begin{array}{c}-0.292 * \\
0.002 \\
0.132\end{array}$ & $\begin{array}{l}-0.054 * * \\
-0.047 * * \\
-0.005\end{array}$ & $\begin{array}{l}-0.042 * * \\
-0.028 * * \\
0.003\end{array}$ & $\begin{array}{r}-0.042 * * \\
-0.027 * * \\
0.005 * *\end{array}$ \\
\hline BET & $\begin{array}{l}\text { Past } \\
\text { Current } \\
\text { Future }\end{array}$ & $\begin{array}{c}0.119 \\
-0.215^{*} \\
0.117\end{array}$ & $\begin{array}{l}-0.061^{* *} \\
-0.100^{* *} \\
-0.018^{*}\end{array}$ & $\begin{array}{l}-0.046^{* *} \\
-0.064^{* *} \\
0.005\end{array}$ & $\begin{array}{r}-0.044^{* *} \\
-0.062^{* *} \\
0.005^{* *}\end{array}$ \\
\hline INDEXP & $\begin{array}{l}\text { Past } \\
\text { Current } \\
\text { Future }\end{array}$ & $\begin{array}{l}0.020 \\
-0.105^{*} \\
-0.043\end{array}$ & $\begin{array}{l}-0.008 \\
-0.011^{*} \\
0.002\end{array}$ & $\begin{array}{l}-0.005^{* *} \\
-0.007 * * \\
-0.001\end{array}$ & $\begin{array}{l}-0.005^{*} \\
-0.007^{* *} \\
-0.001\end{array}$ \\
\hline LTHELD & $\begin{array}{l}\text { Past } \\
\text { Current } \\
\text { Future }\end{array}$ & $\begin{array}{l}0.104^{*} \\
0.254^{* *} \\
0.142^{*}\end{array}$ & $\begin{array}{r}0.005 \\
-0.006 \\
0.006\end{array}$ & $\begin{array}{c}0.006^{*} \\
-0.004 \\
0.000\end{array}$ & $\begin{array}{c}0.006^{*} \\
-0.004 \\
0.001\end{array}$ \\
\hline
\end{tabular}

*,** Significantly different from zero at the $0.05,0.01$ level, respectively, using a two tailed test.

This table reports the summary of the results from Hierarchical Linear Modeling (HLM) regressions where the dependent variable is the change in ownership for an individual institution and the independent variables include private information proxies and the interaction of these proxies with past, current, and future performance measures. We report the average regression coefficient from quarterly regressions with significance tests based on FamaMacBeth t-statistics. There are 79, 87, 87, and 84 quarterly regressions for AFE, CAR, BHAR3, and BHAR12, respectively. All coefficients are multiplied by 100 . All dependent and independent variables are mean centered at the firm-quarter level to remove fixed effects. Intercepts and main effects for all private information proxies are estimated, but not reported. The column labels indicate the definition of performance measure for a given regression. All variable definitions are given in panel A of the Appendix. 
TABLE 5

HLM Regressions of the Change in Institutional Holdings on Performance Measures Interacted with Private Information Proxies and with an Indicator for Large Positions in Firms

\begin{tabular}{|c|c|c|c|c|c|}
\hline \multicolumn{2}{|c|}{ Interactions } & \multicolumn{4}{|c|}{ Performance Measure / Interaction with Block or Bet } \\
\hline & & \multirow{2}{*}{$\begin{array}{c}\text { AFE } \\
\text { Block and Bet }=0\end{array}$} & \multirow{2}{*}{$\begin{array}{c}\text { AFE } \\
\text { Block or Bet }=1\end{array}$} & \multirow{2}{*}{$\begin{array}{c}\text { CAR } \\
\text { Block and Bet }=0\end{array}$} & \multirow{2}{*}{$\begin{array}{c}\text { CAR } \\
\text { Block or Bet }=1\end{array}$} \\
\hline Characteristic & Perf. Period & & & & \\
\hline \multirow[t]{3}{*}{ BANK } & Past & -0.053 & -0.016 & -0.006 & 0.010 \\
\hline & Current & 0.100 & $0.618^{* *}$ & 0.008 & -0.007 \\
\hline & Future & 0.044 & 0.186 & 0.011 & -0.011 \\
\hline \multirow[t]{3}{*}{$\mathrm{P} \& \mathrm{E}$} & Past & -0.104 & 0.024 & -0.007 & $-0.030 *$ \\
\hline & Current & 0.032 & -0.049 & 0.004 & $-0.049 * *$ \\
\hline & Future & 0.077 & -0.228 & $0.022 * *$ & -0.026 \\
\hline \multirow[t]{3}{*}{ IIA } & & $-0.233 * *$ & 0.055 & -0.005 & $-0.050 * *$ \\
\hline & Current & -0.126 & -0.017 & $0.018^{*}$ & $-0.083 * *$ \\
\hline & Future & -0.110 & $0.317 * *$ & 0.013 & -0.018 \\
\hline \multirow[t]{3}{*}{ VALUE } & & $-0.109 *$ & 0.124 & $-0.030 * *$ & $-0.024 *$ \\
\hline & Current & 0.023 & -0.153 & $-0.026^{* *}$ & $-0.096^{* *}$ \\
\hline & Future & $-0.156^{* *}$ & -0.166 & -0.004 & -0.020 \\
\hline \multirow[t]{3}{*}{ GROWTH } & Past & 0.081 & 0.014 & $0.063 * *$ & $-0.047 * *$ \\
\hline & Current & $0.355^{* *}$ & $-0.413^{*}$ & $0.108^{* *}$ & -0.018 \\
\hline & Future & 0.043 & 0.371 & $0.020^{*}$ & -0.017 \\
\hline \multirow[t]{3}{*}{ TRANSIENT } & Past & $0.148 *$ & $-0.378 * *$ & $0.047 * *$ & -0.016 \\
\hline & Current & $0.537 * *$ & -0.091 & $0.081 * *$ & 0.016 \\
\hline & Future & $0.270^{* *}$ & 0.131 & 0.010 & -0.018 \\
\hline \multirow[t]{3}{*}{ LARGE } & Past & 0.107 & $-0.342 *$ & $0.021 * *$ & $-0.038 * *$ \\
\hline & Current & $0.195 * *$ & -0.004 & $0.043 * *$ & -0.026 \\
\hline & Future & 0.058 & 0.171 & 0.004 & 0.008 \\
\hline \multirow[t]{3}{*}{ INDEXP } & Past & 0.040 & -0.072 & -0.005 & -0.011 \\
\hline & Current & -0.019 & $-0.252 *$ & -0.004 & $-0.029^{*}$ \\
\hline & Future & -0.077 & 0.125 & -0.001 & 0.006 \\
\hline \multirow[t]{3}{*}{ LTHELD } & Past & 0.037 & 0.211 & -0.010 & $0.036^{* *}$ \\
\hline & Current & $0.195^{* *}$ & 0.135 & $-0.028 * *$ & $0.058^{* *}$ \\
\hline & Future & $0.191^{* *}$ & -0.213 & 0.000 & 0.023 \\
\hline
\end{tabular}

*, ** Significantly different from zero at the $0.05,0.01$ level, respectively, using a two tailed test. 
TABLE 5 (continued)

HLM Regressions of the Change in Institutional Holdings on Performance Measures Interacted with Private Information Proxies and with an Indicator for Large Positions in Firms

\begin{tabular}{|c|c|c|c|c|c|}
\hline \multicolumn{2}{|c|}{ Interactions } & \multicolumn{4}{|c|}{ Performance Measure / Interaction with Block or Bet } \\
\hline & & \multirow{2}{*}{$\begin{array}{c}\text { BHAR3 } \\
\text { Block and Bet }=0\end{array}$} & \multirow{2}{*}{$\begin{array}{c}\text { BHAR3 } \\
\text { Block or Bet }=1 \\
\end{array}$} & \multirow{2}{*}{$\begin{array}{c}\text { BHAR12 } \\
\text { Block and Bet }=0\end{array}$} & \multirow{2}{*}{$\begin{array}{c}\text { BHAR12 } \\
\text { Block or Bet }=1\end{array}$} \\
\hline Characteristic & Perf. Period & & & & \\
\hline \multirow[t]{3}{*}{ BANK } & Past & 0.000 & $0.020 * *$ & 0.001 & $0.018^{* *}$ \\
\hline & Current & 0.004 & 0.003 & 0.005 & 0.001 \\
\hline & Future & 0.001 & -0.002 & 0.000 & -0.001 \\
\hline \multirow[t]{3}{*}{$\mathrm{P} \& \mathrm{E}$} & Past & 0.000 & $-0.016^{*}$ & 0.000 & $-0.017 * *$ \\
\hline & Current & 0.003 & $-0.034 * *$ & 0.002 & $-0.036^{* *}$ \\
\hline & Future & 0.002 & -0.003 & -0.001 & 0.000 \\
\hline \multirow[t]{3}{*}{ IIA } & Past & -0.002 & $-0.038 * *$ & -0.003 & $-0.038 * *$ \\
\hline & Current & $0.018 * *$ & $-0.039 * *$ & $0.018 * *$ & $-0.039 * *$ \\
\hline & Future & -0.001 & 0.001 & $-0.003^{*}$ & $0.005 * *$ \\
\hline \multirow{3}{*}{ VALUE } & Past & $-0.020 * *$ & $-0.036^{* *}$ & $-0.021 * *$ & $-0.037 * *$ \\
\hline & Current & $-0.025 * *$ & $-0.073 * *$ & $-0.025 * *$ & $-0.075 * *$ \\
\hline & Future & 0.002 & -0.006 & 0.002 & -0.002 \\
\hline \multirow[t]{3}{*}{ GROWTH } & Past & $0.049 * *$ & 0.000 & $0.050^{* *}$ & 0.001 \\
\hline & Current & $0.067 * *$ & -0.012 & $0.069 * *$ & -0.012 \\
\hline & Future & -0.002 & $0.011^{*}$ & $-0.004 *$ & $0.007 * *$ \\
\hline \multirow[t]{3}{*}{ TRANSIENT } & Past & $0.039 * *$ & 0.007 & $0.040 * *$ & 0.008 \\
\hline & Current & $0.054 * *$ & $0.012 *$ & $0.057 * *$ & $0.014 *$ \\
\hline & Future & -0.001 & 0.004 & $-0.002 *$ & 0.003 \\
\hline \multirow[t]{3}{*}{ LARGE } & Past & $0.018 * *$ & $-0.022 * *$ & $0.018 * *$ & $-0.023 * *$ \\
\hline & Current & $0.033 * *$ & $-0.015^{* *}$ & $0.034 * *$ & $-0.015^{* *}$ \\
\hline & Future & -0.002 & 0.006 & $-0.002 *$ & $0.005^{* *}$ \\
\hline \multirow[t]{3}{*}{ INDEXP } & Past & -0.002 & $-0.011 *$ & -0.002 & $-0.011 *$ \\
\hline & Current & -0.004 & $-0.016^{* *}$ & -0.003 & $-0.016^{* *}$ \\
\hline & Future & 0.001 & -0.005 & -0.001 & -0.001 \\
\hline \multirow[t]{3}{*}{ LTHELD } & Past & 0.000 & 0.000 & 0.000 & 0.002 \\
\hline & Current & $-0.015 * *$ & $0.022 * *$ & $-0.016^{* *}$ & $0.024 * *$ \\
\hline & Future & 0.001 & -0.001 & $0.002 *$ & $-0.003 *$ \\
\hline
\end{tabular}

$*, * *$ Significantly different from zero at the $0.05,0.01$ level, respectively, using a two tailed test.

This table reports the summary of the results from Hierarchical Linear Modeling (HLM) regressions where the dependent variable is the change in ownership for an individual institution and the independent variables include private information proxies and the interaction of these proxies with past, current, and future performance measures. These variables are further interacted with an indicator for whether the institution has a large position in the firm, in terms of percentage ownership or percent of portfolio (Block or Bet $=1$ ), or a small position (Block and Bet $=0$ ). We report the average regression coefficient from quarterly regressions with significance tests based on Fama-MacBeth t-statistics. There are 79, 87, 87, and 84 quarterly regressions for AFE, CAR, BHAR3, and BHAR12, respectively. All coefficients are multiplied by 100. All dependent and independent variables are mean centered at the firmquarter level to remove fixed effects. Intercepts and main effects for all private information proxies are estimated, but not reported. The column labels indicate the definition of performance measure for a given regression and the interaction with the Block or Bet indicator. All variable definitions are given in panel A of the Appendix. 
TABLE 6

HLM Regressions of the Change in Institutional Holdings on Performance Measures Interacted with Private Information Proxies and with an Indicator for Long-Term Holdings of a Firm

\begin{tabular}{|c|c|c|c|c|c|}
\hline \multicolumn{2}{|c|}{ Interactions } & \multicolumn{4}{|c|}{ Performance Measure / Interaction with LTHELD } \\
\hline & & \multirow{2}{*}{$\begin{array}{c}\text { AFE } \\
\text { LTHELD }=0\end{array}$} & \multirow{2}{*}{$\begin{array}{c}\text { AFE } \\
\text { LTHELD }=1\end{array}$} & \multirow{2}{*}{$\begin{array}{c}\text { CAR } \\
\text { LTHELD }=0\end{array}$} & \multirow{2}{*}{$\begin{array}{c}\text { CAR } \\
\text { LTHELD = } 1\end{array}$} \\
\hline Characteristic & Perf. Period & & & & \\
\hline \multirow[t]{3}{*}{ BANK } & Past & -0.126 & 0.112 & -0.018 & $0.018^{*}$ \\
\hline & Current & 0.030 & $0.350^{*}$ & $-0.027 * *$ & $0.048^{* *}$ \\
\hline & Future & 0.009 & 0.124 & 0.004 & 0.004 \\
\hline \multirow[t]{3}{*}{$\mathrm{P} \& \mathrm{E}$} & Past & $-0.218^{*}$ & 0.129 & $-0.032 *$ & 0.016 \\
\hline & Current & -0.168 & $0.227 *$ & $-0.028 *$ & 0.024 \\
\hline & Future & -0.018 & 0.017 & 0.019 & -0.011 \\
\hline \multirow[t]{3}{*}{ IIA } & & $-0.333 * *$ & 0.140 & $-0.024 *$ & -0.003 \\
\hline & Current & $-0.378 * *$ & $0.378^{* *}$ & -0.017 & 0.017 \\
\hline & Future & -0.140 & $0.184^{*}$ & 0.011 & -0.003 \\
\hline \multirow[t]{3}{*}{ VALUE } & & $-0.176^{*}$ & 0.149 & $-0.056 * *$ & $0.032 * *$ \\
\hline & Current & -0.016 & -0.005 & $-0.057 * *$ & 0.009 \\
\hline & Future & $-0.269 * *$ & 0.092 & -0.009 & -0.001 \\
\hline \multirow[t]{3}{*}{ GROWTH } & Past & 0.001 & 0.072 & $0.062 * *$ & $-0.044 * *$ \\
\hline & Current & $0.400^{* *}$ & $-0.377^{*}$ & $0.157^{* *}$ & $-0.107 * *$ \\
\hline & Future & 0.014 & 0.182 & 0.020 & -0.013 \\
\hline \multirow[t]{3}{*}{ TRANSIENT } & Past & 0.103 & -0.182 & $0.050^{* *}$ & $-0.027^{*}$ \\
\hline & Current & $0.655^{* *}$ & $-0.358 * *$ & $0.100^{* *}$ & $-0.040 * *$ \\
\hline & Future & $0.382^{* *}$ & -0.205 & 0.010 & -0.012 \\
\hline \multirow[t]{3}{*}{ LARGE } & Past & $0.148^{*}$ & $-0.224 * *$ & 0.005 & -0.009 \\
\hline & Current & 0.154 & -0.055 & $0.046^{* *}$ & $-0.041 * *$ \\
\hline & Future & 0.076 & -0.009 & 0.005 & 0.006 \\
\hline \multirow[t]{3}{*}{ BLOCK } & Past & $-0.618^{* *}$ & $0.512 * *$ & $-0.076^{* *}$ & $0.047 *$ \\
\hline & Current & $-0.451^{*}$ & $0.672 *$ & $-0.114 * *$ & $0.106^{* *}$ \\
\hline & Future & 0.463 & -0.400 & -0.031 & 0.035 \\
\hline \multirow[t]{3}{*}{ BET } & Past & 0.153 & -0.033 & $-0.061 * *$ & 0.018 \\
\hline & Current & -0.045 & -0.159 & $-0.091 * *$ & 0.003 \\
\hline & Future & 0.068 & 0.006 & -0.028 & 0.026 \\
\hline \multirow[t]{3}{*}{ INDEXP } & Past & -0.005 & 0.061 & -0.008 & 0.001 \\
\hline & Current & -0.093 & -0.015 & -0.011 & 0.000 \\
\hline & Future & -0.102 & 0.075 & -0.007 & 0.015 \\
\hline
\end{tabular}

*, ** Significantly different from zero at the $0.05,0.01$ level, respectively, using a two tailed test. 


\section{TABLE 6 (continued)}

HLM Regressions of the Change in Institutional Holdings on Performance Measures Interacted with Private Information Proxies and with an Indicator for Long-Term Holdings of a Firm

\begin{tabular}{|c|c|c|c|c|c|}
\hline \multicolumn{2}{|c|}{ Interactions } & \multicolumn{4}{|c|}{ Performance Measure / Interaction with Block or Bet } \\
\hline & & \multirow{2}{*}{$\begin{array}{c}\text { BHAR3 } \\
\text { LTHELD }=0\end{array}$} & \multirow{2}{*}{$\begin{array}{c}\text { BHAR3 } \\
\text { LTHELD = } 1\end{array}$} & \multirow{2}{*}{$\begin{array}{c}\text { BHAR12 } \\
\text { LTHELD =0 }\end{array}$} & \multirow{2}{*}{$\begin{array}{c}\text { BHAR12 } \\
\text { LTHELD = } 1\end{array}$} \\
\hline Characteristic & Perf. Period & & & & \\
\hline \multirow[t]{3}{*}{ BANK } & Past & $-0.010^{*}$ & $0.023 * *$ & -0.009 & $0.022 * *$ \\
\hline & Current & $-0.014 * *$ & $0.027 * *$ & $-0.013 * *$ & $0.026^{* *}$ \\
\hline & Future & 0.002 & -0.003 & 0.001 & -0.001 \\
\hline \multirow[t]{3}{*}{ P\&E } & Past & $-0.013^{*}$ & 0.009 & $-0.013^{*}$ & 0.010 \\
\hline & Current & $-0.020 * *$ & $0.018 * *$ & $-0.022 * *$ & $0.019^{* *}$ \\
\hline & Future & 0.006 & -0.007 & -0.001 & 0.000 \\
\hline \multirow[t]{3}{*}{ IIA } & & $-0.020 * *$ & 0.008 & $-0.021 * *$ & 0.008 \\
\hline & Current & 0.000 & $0.010^{*}$ & -0.001 & $0.011 *$ \\
\hline & Future & 0.001 & -0.002 & -0.002 & 0.003 \\
\hline \multirow[t]{3}{*}{ VALUE } & & $-0.034 * *$ & $0.008^{*}$ & $-0.035^{* *}$ & $0.009^{*}$ \\
\hline & Current & $-0.046 * *$ & 0.002 & $-0.046^{* *}$ & 0.001 \\
\hline & Future & 0.001 & -0.002 & 0.003 & $-0.003 *$ \\
\hline \multirow[t]{3}{*}{ GROWTH } & Past & $0.056^{* *}$ & $-0.021 * *$ & $0.058 * *$ & $-0.021 * *$ \\
\hline & Current & $0.084 * *$ & $-0.041 * *$ & $0.086^{* *}$ & $-0.042 * *$ \\
\hline & Future & -0.003 & $0.009^{*}$ & -0.003 & $0.004 *$ \\
\hline \multirow[t]{3}{*}{ TRANSIENT } & Past & $0.046^{* *}$ & $-0.016^{* *}$ & $0.048^{* *}$ & $-0.016^{* *}$ \\
\hline & Current & $0.069 * *$ & $-0.028 * *$ & $0.073 * *$ & $-0.030 * *$ \\
\hline & Future & -0.001 & 0.003 & -0.002 & 0.002 \\
\hline \multirow[t]{3}{*}{ LARGE } & Past & $0.008^{*}$ & -0.004 & $0.008 * *$ & -0.004 \\
\hline & Current & $0.032 * *$ & $-0.025 * *$ & $0.034^{* *}$ & $-0.026^{* *}$ \\
\hline & Future & -0.001 & 0.003 & 0.001 & 0.000 \\
\hline \multirow[t]{3}{*}{ BLOCK } & Past & $-0.042 * *$ & 0.009 & $-0.042 * *$ & 0.010 \\
\hline & Current & $-0.052 * *$ & $0.041 * *$ & $-0.053^{* *}$ & $0.043^{* *}$ \\
\hline & Future & 0.009 & -0.009 & $0.009 * *$ & -0.006 \\
\hline \multirow[t]{3}{*}{ BET } & Past & $-0.034 * *$ & -0.010 & $-0.034 * *$ & -0.008 \\
\hline & Current & $-0.057 * *$ & -0.004 & $-0.056^{* *}$ & -0.003 \\
\hline & Future & 0.000 & 0.007 & $0.005^{*}$ & -0.001 \\
\hline \multirow[t]{3}{*}{ INDEXP } & Past & -0.005 & 0.001 & -0.005 & 0.001 \\
\hline & Current & $-0.012 * *$ & $0.009 *$ & $-0.012 * *$ & $0.009 *$ \\
\hline & Future & 0.000 & -0.002 & -0.002 & 0.001 \\
\hline
\end{tabular}

*, ** Significantly different from zero at the $0.05,0.01$ level, respectively, using a two tailed test.

This table reports the summary of the results from Hierarchical Linear Modeling (HLM) regressions where the dependent variable is the change in ownership for an individual institution and the independent variables include private information proxies and the interaction of these proxies with past, current, and future performance measures. These variables are further interacted with an indicator for whether the institution has a long-term position in the firm; i.e., held continuously for four quarters or more $(L T H E L D=1$ ), or a relatively new position (LTHELD $=0$ ). We report the average regression coefficient from quarterly regressions with significance tests based on FamaMacBeth t-statistics. There are 79, 87, 87, and 84 quarterly regressions for AFE, CAR, BHAR3, and BHAR12, respectively. All coefficients are multiplied by 100. All dependent and independent variables are mean centered at the firm-quarter level to remove fixed effects. Intercepts and main effects for all private information proxies are estimated, but not reported. The column labels indicate the definition of performance measure for a given regression and the interaction with the LTHELD indicator. All variable definitions are given in panel A of the Appendix. 